\title{
Biosensing Applications Using Nanostructure-Based Localized Surface Plasmon Resonance Sensors
}

\author{
Dong Min Kim ${ }^{1}$, Jong Seong Park ${ }^{2}$, Seung-Woon Jung ${ }^{2}$, Jinho Yeom ${ }^{2}$ and Seung Min Yoo ${ }^{2, *}$ \\ 1 Center for Applied Life Science, Hanbat National University, Daejeon 34158, Korea; dmk.iqbio@gmail.com \\ 2 School of Integrative Engineering, Chung-Ang University, Seoul 06974, Korea; toxiart@gmail.com (J.S.P.); \\ bioboyandy@gmail.com (S.-W.J.); jinho0134@gmail.com (J.Y.) \\ * Correspondence: yooseun1@cau.ac.kr
}

Citation: Kim, D.M.; Park, J.S.; Jung, S.-W.; Yeom, J.; Yoo, S.M. Biosensing Applications Using

Nanostructure-Based Localized Surface Plasmon Resonance Sensors. Sensors 2021, 21, 3191. https:// doi.org/10.3390/s21093191

Academic Editors: Pietro Salvo, Tommaso Lomonaco and Luisa Pozzo

Received: 11 April 2021

Accepted: 3 May 2021

Published: 4 May 2021

Publisher's Note: MDPI stays neutral with regard to jurisdictional claims in published maps and institutional affiliations.

Copyright: (c) 2021 by the authors. Licensee MDPI, Basel, Switzerland. This article is an open access article distributed under the terms and conditions of the Creative Commons Attribution (CC BY) license (https:/ / creativecommons.org/licenses/by/ $4.0 /)$.

\begin{abstract}
Localized surface plasmon resonance (LSPR)-based biosensors have recently garnered increasing attention due to their potential to allow label-free, portable, low-cost, and real-time monitoring of diverse analytes. Recent developments in this technology have focused on biochemical markers in clinical and environmental settings coupled with advances in nanostructure technology. Therefore, this review focuses on the recent advances in LSPR-based biosensor technology for the detection of diverse chemicals and biomolecules. Moreover, we also provide recent examples of sensing strategies based on diverse nanostructure platforms, in addition to their advantages and limitations. Finally, this review discusses potential strategies for the development of biosensors with enhanced sensing performance.
\end{abstract}

Keywords: localized surface plasmon resonance; detection; nanoparticle; nanostructure; biomolecule

\section{Introduction}

Biosensors are analytical devices that consist of biological recognition elements, transducer components, and electronic systems. These devices are typically used to detect and monitor chemicals and biomolecules in clinical and environmental settings. In particular, point-of-care (POC) testing and monitoring has become an ongoing trend for the development of medical and environmental applications due to the increasing need for user (patient)-centered systems, and more convenient, inexpensive, portable, and accurate detection systems that can be easily deployed in a wide variety of scenarios [1]. A recent report by the World Health Organization (WHO) suggested that the ideal analytical method should be affordable, sensitive, specific, user-friendly, rapid and robust, equipment-free, and deliverable to end-users. These criteria, represented by the acronym ASSURED, provide a framework for the evaluation of detection devices, especially in resource-limited regions or field applications. Biosensor development entails not only the fabrication of detection devices but also evaluating their sensing performance. Fabrication often involves the selection of a substrate and receptor, followed by functionalization of the substrate with the receptor. The sensing performance of the newly-developed device is then validated by analyzing the signals generated by the chemical reaction between the receptor and a target analyte (e.g., pathogenic microorganisms or their nucleic acids). Importantly, the fabrication and evaluation phases provide a crucial basis for the improvement of signal intensity and accuracy.

Biosensors are typically classified based on transducer type as optical, thermal, piezoelectric, quartz crystal microbalance, and electrochemical, among others. Among these, optical biosensors allow for practical, rapid, portable, and cost-effective detection and monitoring of diverse chemicals and biomolecules [1]. Further, plasmonic sensors, a type of optical sensors, offer high sensitivity and multiplexing capability and do not require relatively expensive proprietary instruments. Therefore, several types of plasmonic sensors have been developed to date, including surface plasmon resonance (SPR) [2], long-range 
surface plasmon polariton (LRSPP) [3], surface-enhanced Raman scattering (SERS) [4,5], and localized surface plasmon resonance (LSPR) $[1,6,7]$ sensors. LSPR biosensors offer several advantages over other plasmonic sensors, including their inherent label-free nature, portability, low cost, and real-time sensing capacity. Additionally, nanostructure platformbased LSPR biosensors are under active commercial development, and some have even been commercially launched by several companies such as LSPR AG Co., LamdaGen Co., and others. Therefore, it is expected that LSPR sensors will have increasingly important roles in POC testing and monitoring in both clinical and environmental settings.

There are many good reviews that provide detailed information on the principles and characteristics of LSPR technology [8-12]. In this article, focus is given to the biomoleculedetecting strategies and technologies based in diverse nanostructure platforms, which can be divided into three different categories: solution phase-based colloidal nanoparticles, flat substrate-based platforms, and nanoparticle (NP)-coated optical fiber platforms. Representative applications of these strategies, including those described in this paper and others that have been developed and employed for the detection of a wide range of chemical and biomolecules, are also described in Table 1. Discussion of potential challenges and strategies to improve the performance of LSPR biosensors, summarized in Table 2, will be helpful to all researchers in the development of LSPR sensors for biosensing applications. An approach that may enable the development of biosensors with an enhanced sensing performance for POC detection is described to help achieve the long-term goal of its practical use.

\section{LSPR Biosensors for POC Molecule Detection and Monitoring}

LSPR is a phenomenon that occurs when the electromagnetic radiation of incident light interacts with the free electrons of metal nanostructures. Upon light incidence, resonance occurs if the frequency of the collective electron oscillations matches that of the conduction band of the metal, after which most of the light energy is transferred to free electrons. When surface waves occur, this phenomenon is referred to as surface plasmon resonance (SPR). Linear polarized free-space incident light generates an electric field at the plasmonic surface, after which light-induced surface plasmon polariton (SPP) propagates along the surface, thereby reducing spatial resolution. However, when light is irradiated onto plasmonic nanoparticles or nanostructured surfaces, the SPP is confined to the surrounding nanoparticles or nanostructures. This strong enhancement of the local electromagnetic fields generated at the nanostructure level occurs due to the frequencymatched collective oscillation of electrons in the conduction band of the metal. The intensity of the generated electromagnetic field is dramatically enhanced in these circumstances but decreases sharply as the distance from the surface increases [13]. Therefore, LSPR refers specifically to non-propagating plasmon modes. LSPR biosensors take advantage of the aforementioned plasmonic properties of noble metals and strong electromagnetic fields created upon plasmon resonance around confined structures. Therefore, nanostructure is an important factor that affects biosensor sensitivity. Resonance depends on the size, shape, material, composition, surface modification, interparticle spacing, dielectric environment, and separation distance of the conductive band [14-17]. Variations in nanostructure or nanoparticles with separations of a few nanometers can further amplify the amplitude of the confined electromagnetic field. An enhanced electromagnetic field intensity can allow for the sensitive detection (e.g., single-molecule detection) of molecules bound to the surface or to nanoparticles [13,18]. The binding of analytes on surfaces leads to a change in the refractive index of the surrounding medium such as the metallic surface, which can be identified as a wavelength shift or a change in LSPR peak intensity.

Many efforts have been made to develop LSPR-based sensors for clinical and environmental applications, because LSPR sensing approaches offer many advantages in POC monitoring and point of view detection. More importantly, LSPR-based sensors enable on-site measurement. This is largely because this technology does not require modifications or further labeling of analytes, thus enabling simple and rapid detection of target molecules. This label-free detection is possible because changes in intensity and wave- 
length shifts occur solely via the interaction between the analyte in the samples and the receptor immobilized on the nanostructure without the need for any conjugating reporter molecules. Moreover, this procedure is not affected by temperature or sample composition, among other factors $[13,19]$. In particular, this type of sensor is suitable for the detection of molecules in biological samples and clinical specimens because these sensors are unaffected by ionic properties [20]. The stability of LSPR in response to environmental changes is due to its compact sensing volume and short electromagnetic field decay length, resulting in a higher sensitivity to molecular binding and lower sensitivity to bulk refractive index changes. Moreover, given that LSPR focuses on a spectral shift and not an angle change, it is much more resistant to environmental vibration and mechanical noise than other similar approaches [21]. The simple design and portability of LSPR instruments are additional advantages of POC sensors. In particular, LSPR sensors do not require prisms to refract the incident light and therefore LSPR-based optical hardware is much less complex, smaller, and more affordable. As mentioned previously, given that LSPR is less susceptible to temperature changes and does not require strict temperature control, LSPR instruments can be much simpler and easier to use and maintain. Therefore, the applications of LSPR sensors could soon expand to food, beverage, and drinking water safety testing, in addition to disease diagnostics. The following sections highlight relevant LSPR biosensors that have been applied for biomolecule and chemical detection in clinical analyses and environmental monitoring.

The molecule-detecting performance of LSPR sensors largely depends on the distribution and concentration of hot spots. These hot spots are confined locations in close proximity to nanostructures in which the highest electromagnetic field strengths occur. A high abundance of hot spots on the nanostructure leads to a large change in the resonance wavelength shifts caused by analytes adsorbed on the surface, thereby enhancing the sensitivity of the sensor. Regular hot spots generated on uniform nanostructures result in sharp and clean resonance spectra, thus providing a reliable and reproducible result. The structures used for LSPR sensors can be classified into three different categories: (1) solution phase-based colloidal nanoparticles, (2) flat substrate-based platforms, and (3) NP-coated optical fiber platforms.

\section{Current LSPR Biosensors for the Detection of Chemical and Biomolecules}

Challenges and strategies to improve the performance of LSPR biosensors, and the related parameters (linear range, LoD, assay time, etc.) are summarized in Tables 1 and 2, respectively.

\subsection{LSPR Sensors Coupled with Solution Phase-Based Nanoparticles}

The use of solution phased nanoparticles can be advantageous for the fabrication of substrates, because the nanoparticles themselves can act as an LSPR substrate without additional processing requirements. Solution-based biosensors generally use colloidal nanoparticles and non-spherical shapes such as rods and spheres, which are commonly used as LSPR substrates. The aggregation or self-assembly of nanoparticles, nanorods, and nanowires results in randomly distributed nanostructured colloids. In these structures, hot spots can be generated at the poles of the nanospheres near areas of higher surface curvatures, gaps, or junctions, resulting in a high refractive index change sensitivity [3,22-24]. Advances in nanoparticle synthesis and nanofabrication techniques have also allowed for the development of metallic nanostructures. Metal nanoparticles with specific geometries such as nanoprisms $[25,26]$ exhibit higher electromagnetic field strengths than isotropic nanoparticles due to the accumulation of oscillating charges on the edges of the anisotropic nanoparticles. Additionally, nanostructures can be formed from self-assembled nanoparticles linked through functionalization with molecules, where the molecule size determines the distance of the gap between the nanostructures. Therefore, different molecules will result in gap variations, resulting in enhanced hot spot effects [27-29]. Self-assembled nanoparticles can also form randomly misaligned structures, where edge-to-edge nanoparticles (i.e., gaps) induce a double resonance effect [30]. Importantly, nanoparticle length 
misalignment and thickness can determine double resonance strength and position. These optical properties may therefore contribute to the development of nanoswitches, nanomotors, nanorulers, and dual-channel biosensors [25].

The compositions of the nanoparticles used as LSPR substrates are additional factors that determine sensitivity. Several types of metal-based (e.g., europium, gold, silver, and copper) and non-metal-based (e.g., graphene, silica, and carbon nanotubes) nanoparticles have been used in biosensing to monitor a variety of biological analytes [31]. Conventional LSPR biosensors typically use coinage metal (e.g., $\mathrm{Au}$ and Ag) nanoshells, because they can support NP plasmon resonances in the ultraviolet, visible, and near-infrared regions of the spectrum, and are modifiable by adjusting the NP size and shape. AuNPs have a wide light absorption and scattering cross-section in the SPR wavelength regions. Due to their LSPR properties, self-assembly technology has led to the diversification of sensing structures, which now include gold dimers, trimmers, core-satellites, and clusters, among others [32-35], all of which exhibit plasmon coupling effects. Moreover, many methods involving oligonucleotide-AuNP have been widely adopted. For instance, a recent study reported the use of $\mathrm{Au}$ core-satellite structures containing $\mathrm{Hg}^{2+}$ for the detection of glutathione (GSH) ([36]; Figure 1A). This structure was first synthesized by assembling different-sized AuNPs (50 nm NPs for the core and $13 \mathrm{~nm}$ NP for satellites), which consisted of functionalized DNA strands with complementary sequences that acted as linkers bridging two different AuNPs via base pairs. To endow this structure with the ability to detect GSH, the authors took advantage of the distinct capacity of GSH to bind to specific heavy metal ions such as $\mathrm{Hg}^{2+}, \mathrm{Cd}^{2+}$, and $\mathrm{Pb}^{2+}$. Therefore, $\mathrm{Hg}^{2+}$ was added to the structure by incorporating it into the DNA duplex via $\mathrm{T}-\mathrm{Hg}^{2+}-\mathrm{T}$ base pairing. When $\mathrm{GSH}$ is present in the sample, the higher affinity of GSH and $\mathrm{Hg}^{2+}$ than that of T- $\mathrm{Hg}^{2+}$ - $\mathrm{T}$ leads to a structural collapse, resulting in a strong blue shift in the LSPR peak $(0.1 \mu \mathrm{M}$ detection limit) within $30 \mathrm{~min}$.

A
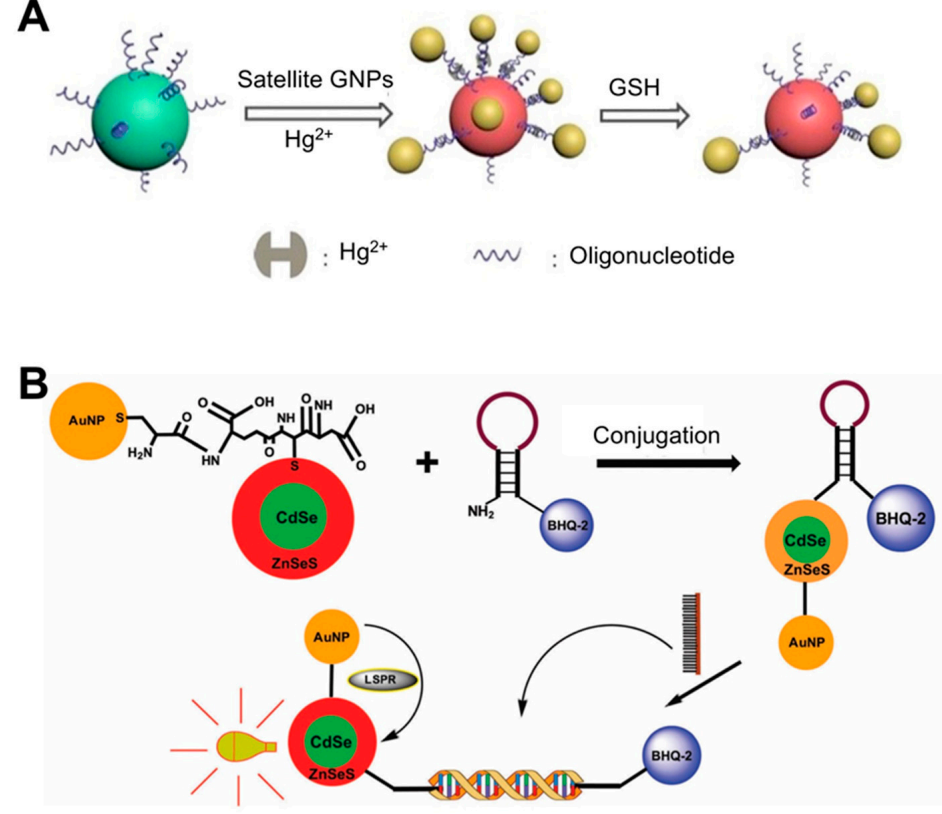

Figure 1. LSPR biosensing strategies based on solution phase-based nanoparticles: (A) Glutathione (GSH) detection using Au core-satellite structures containing $\mathrm{Hg}^{2+}$. Reproduced with permission from [36]; (B) Detection of dengue virus using CdSe/ZnSeS core/alloyed shell quantum dots via band-gap engineering. Reproduced with permission from [7]. GNP, gold nanoparticle.

Some studies have conjugated AuNPs and other materials to improve sensing performance. For example, the conjugation of AuNPs and quantum dots (Qdots) results in an intense and narrow luminescence emission, photostability, low toxicity, and broad absorption wavelengths. When Qdots are conjugated with AuNPs, the LSPR from the surfaces 
of the AuNPs enhances the fluorescence intensity of the Qdots and therefore photoluminescence (PL) emission increases [37-39]. Using these characteristics, a biosensor for four different serotypes of dengue virus was developed using CdSe/ZnSeS core/alloyed shell Qdots via band-gap engineering to generate specular optical properties ([7]; Figure 1B). This band-gap engineering approach was achieved via passivation with a ternary alloyed shell layer. To detect the viral DNA, the authors employed a molecular beacon (MB) containing a sequence that was complementary to the target DNA whose ends were attached with BHQ-2 as a quencher and AuNP-Qdot as a fluorophore reporter. If a given sample did not have a target DNA, the MB would continue forming a stem-loop, where BHQ2 quenches the LSPR fluorescence of the AuNP-Qdot, because these molecules were in close proximity. When target DNA is present in the sample, the MB can hybridize with the DNA, thereby undergoing conformational changes and emitting a PL signal. Using this system, the dengue virus was detected with a detection limit of 20 copies $/ \mathrm{mL}$.

Sensors that employ salt-induced AuNP aggregation often undergo non-specific (i.e., unintended) absorption of analytes, inhibiting salt aggregation and lowering the accuracy of the sensor. For example, aromatic compounds such as ochratoxin A (OTA), adenosine triphosphate (ATP), and $17 \beta$-estradiol have an affinity toward Au and therefore this interaction prevents salt-induced AuNP aggregation. If OTA is mixed with ochratoxinspecific aptamer-bound AuNPs, aptamers prefer to bind to OTA, which results in a saltinduced NP aggregation and a purple coloration. However, at high OTA concentrations, OTA binds to both the AuNP surface and the aptamer, and therefore the lack of AuNP aggregation is directly caused by OTA and not by the aptamer. To accurately quantify OTA, Liu et al. used a double calibration curve method [40], where different calibration curves were adopted depending on the OTA concentration. Using this method, OTA could be quantitatively detected in $15 \mathrm{~min}$ within a $0.0316-310 \mathrm{ng} / \mathrm{mL}$ range. Despite many advances in the solution phase NP-based strategy, additional efforts are continuously required to accurately and consistently control the size and shape of NPs, both of which directly affect the sensitivity, specificity, and reproducibility of sensing procedures.

\subsection{LSPR Sensors Using Flat Substrate-Based Platforms}

Compared to colloidal nanoparticles, flat substrate-based LPSR sensors provide higher reproducibility and allow for the detection of multiple targets. These sensors largely fall within two sensing platforms: uniformly distributed NPs on a substrate and periodic nanopatterns.

Deposition of nanomaterials on flat substrates can be achieved via annealing and deposition procedures using focused ion beams, holographic lithography, nanosphere lithography, elastic soft lithography, and template stripping [41-43]. Using this approach, diverse nanostructures, such as nanoshells, dimer/trimer nanoantennas, nanostars, nanocrescents, and nanopyramid arrays have been produced and deposited on diverse flat substrates [44-49]. Periodic nanopatterns can be fabricated using electron beam lithography or mask-assisted techniques, which render regular patterns such as nanoholes, nanofillars, and nanodisks [50-54]. Flat substrate-based LSPR sensors facilitate data acquisition because they feature a high signal-to-noise ratio and thus a high sensitivity compared to LSPR sensing systems based on isolated NPs [55-57]. However, their production entails multiple steps and high costs [58].

Most flat substrate-based LSPR sensors use glass as a flat substrate on which to deposit AuNPs [31,57,59-64]. One of the simplest ways to fabricate such LSPR sensing substrates is to dip glass coated with $0.5 \%$ 3-aminopropyltriethoxysilane (APTES) as an amine group linker into an AuNP solution ([57]; Figure 2A). Once uniformly coated with AuNPs, the substrate (glass) exhibits a high absorbance signal. To detect bacterial cells using this substrate, Oh et al. immobilized thiolated species-specific aptamers on the substrate and incubated with whole cells, including Salmonella typhimurium, Lactobacillus acidophilus, and Pseudomonas aeruginosa. This sensor achieved a $10^{4} \mathrm{CFU} / \mathrm{mL}$ limit of detection within 30-35 min. They further optimized the production conditions for AuNP-deposited glass 
substrates [60]. Specifically, the authors investigated the effect of glass thickness and quality on the properties of the final product. All substrates exhibited a uniform and dense AuNP deposition layer. To achieve this, the glass was treated with $0.5 \%$ of APTES at $60{ }^{\circ} \mathrm{C}$ and then incubated with an AuNP solution for $8 \mathrm{~h}$. To detect $\mathrm{C}$-reactive protein (CRP) using this substrate, the substrate was additionally incubated with anti-CRP antibody, resulting in an $11.28 \mathrm{ng} / \mathrm{mL}$ limit of detection with a $0.01-10 \mu \mathrm{g} / \mathrm{mL}$ quantifiable range.
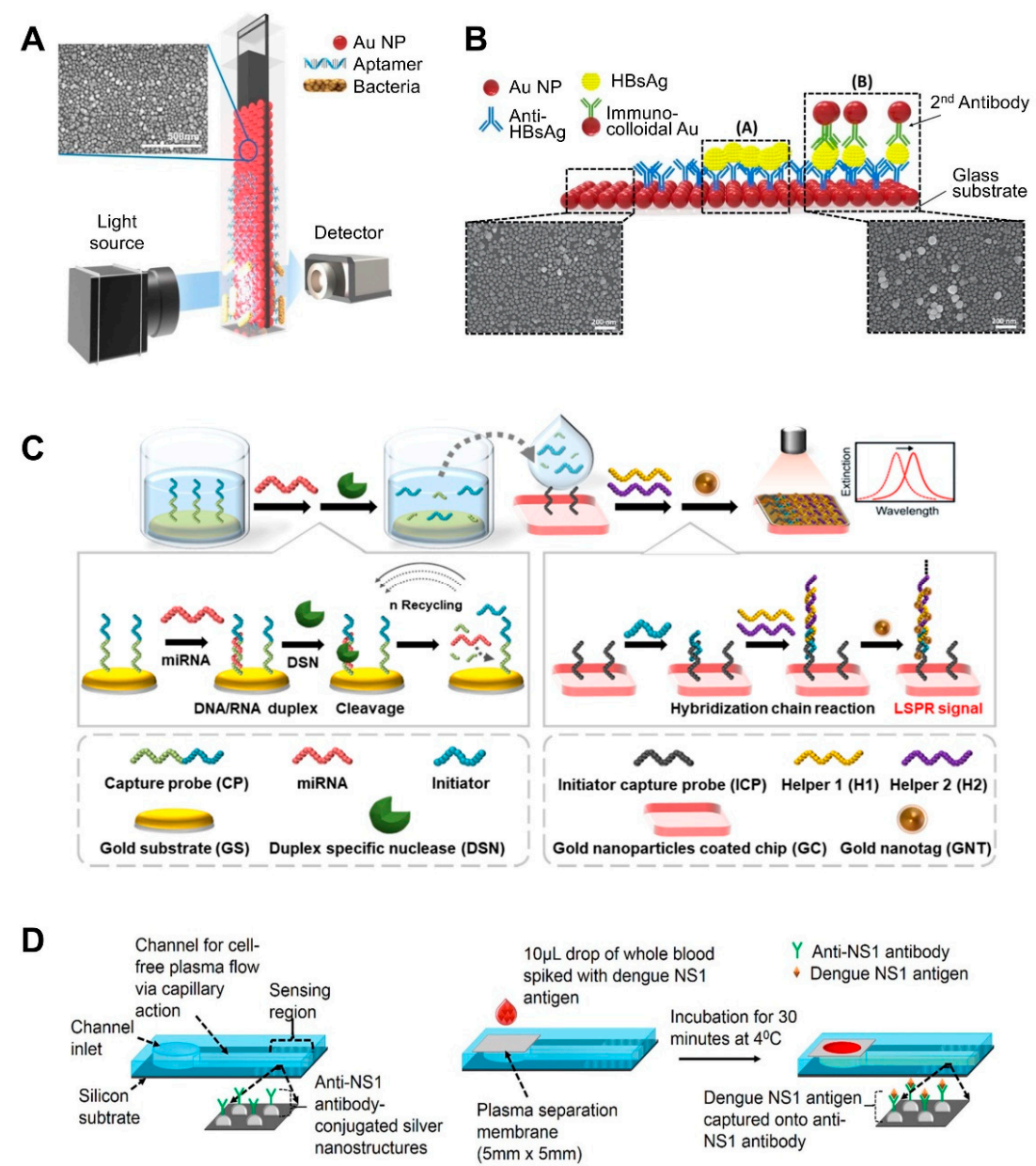

Figure 2. LSPR biosensing strategies based on nanoparticle (NP)-deposited flat substrates: (A) Detection of bacterial cells using aptamer-functionalized Au-coated glass slides. Reproduced with permission from [57]; (B) Detection of hepatitis B surface antigen (HBsAg) using a heteroassembled sandwich structure on a glass slide consisting of antibody-conjugated AuNPs and anti-HBsAgconjugated AuNPs. Reproduced with permission from reference [59]; (C) Detection of miRNA using a duplex-specific nuclease-mediated target recycling reaction-coupled LSPR sensor on a Au substrate. Reproduced with permission from [63]; (D) Detection of the NS1 antigen of the dengue virus in whole blood using a silver NP-deposited silicon substrate functionalized with antibodies, which was coupled with a polyethersulfone membrane filter at the inlet of the biosensor for plasma separation. Reproduced with permission from [65].

$\mathrm{Au}$ nanorod (GNR) was also deposited on the glass and applied to detect various biomolecules [61,62]. To improve the LSPR signal of the GNR substrate, a signal enhancer molecule (i.e., berberine) was used for improving the LSPR signal shift [61]. Berberine makes the LSPR signal more red-shifted by intercalating itself into the G-quadruplex structure formed when the aptamer binds to the analyte and suffers a conformational change, resulting in enhanced sensitivity and broader dynamic range compared to berberine-free sensors. This sensor could detect OTA, aflatoxin B1, ATP, and $\mathrm{K}^{+}$at sensitivities of $0.56,0.63$, 0.87 , and $1.05 \mathrm{pM}$, respectively, accounting for a 1000-fold increase in the detection limit with 
a broad dynamic range of $10 \mathrm{pM}$ to $10 \mu \mathrm{M}$ with linearity. As another means to improve the LSPR signal, the surface of the GNRs was functionalized with citrate as a stabilizer [62]. The surface modification with citrate offered a good dispersion of the GNR particles without surfactant and high immobilization efficiency of GNR on substrate, resulting in a large peak shift. The improved LSPR sensor could detect 25 -hydroxyvitamin $\mathrm{D}_{3}$ down to $0.1 \mathrm{ng} / \mathrm{mL}$.

AuNPs can form multiple layers on flat substrate by sequentially binding to other different-sized NPs, which can enhance sensitivity. For example, heteroassembled sandwich structure-based LSPR sensors have been developed for the detection of hepatitis B surface antigen (HBsAg) ([59]; Figure 2B). This sensor substrate was prepared by depositing Ab-conjugated AuNPs on glass and then exposing it to HBsAg. Then, additional antiHBsAg-conjugated AuNPs were added, thus forming a sandwich structure. This AuNP bilayer provided enhanced LSPR signals, and smaller immunocolloidal AuNPs rendered stronger LSPR signals, because smaller NPs result in more hot spots. This sensor could detect HBsAg down to $100 \mathrm{fg} / \mathrm{mL}$ in $15 \mathrm{~min}$ within a $10 \mathrm{ng} / \mathrm{mL}$ to $100 \mathrm{fg} / \mathrm{mL}$ linear range.

After the deposition of AuNPs on flat substrate, this platform-based sensing approach can be additionally combined with enzyme reaction-assisted signal amplification methods, which can also enhance their sensitivity ([63]; Figure 2C). In particular, the distinct catalytic activities and enzymatic activities of DNA-modifying enzymes, such as DNA polymerases, nicking endonuclease, exonucleases, and ligases, could be used to enhance biosensor sensitivity and specificity due to their specific recognition capabilities and characteristic functional mechanisms [64]. Ki et al. developed a miRNA-detecting LSPR biosensor that incorporated signal amplification using a duplex-specific nuclease (DSN) [63]. In this study, capture probe consists of two parts: the first part contained sequences complementary to specific miRNA to form a DNA:RNA duplex and the other contained sequences that acted as initiators in the following step. Capture probe was first immobilized on an Au flat surface. When specific miRNA was present in a sample, miRNA formed duplexes with the capture probe. Given that DSN can only digest the DNA portion of the DNA:RNA duplex, except for the ssDNA part, the miRNA can dissociate from the duplex and participate in another binding event with the surface-bound Au. This miRNA reaction continues in a cycle, which is the first factor that improves the sensitivity of the sensor. By comparison, the remaining ssDNA portion (i.e., the initiator) of the capture probe sequentially binds to helper probes immobilized on another Au surface, thus forming sandwich self-assemblies. This second factor also enhances the sensitivity of the sensor. The third sensitivity-enhancing factor was the use of tannic acid-capped AuNPs. Tannic acid is a gallol-rich hydrophilic polyphenolic compound, which can bind to the phosphate backbone of DNA via hydrogen bonding. The resulting initiator-helper DNA-AuNPs complex dramatically changed the LSPR peak and therefore this sensor exhibited a linear range from $5 \mathrm{pM}$ to $10 \mathrm{nM}$ with a $2.45 \mathrm{pM}$ miRNA limit of detection.

The deposition of NPs with different sizes and shapes on substrates can be used to detect multiple biomolecules because these NPs have different optical properties. A shapecode biosensor was developed using three different NP types (AuNPs (50 nm diameter), short NRs (1.6 aspect ratio), and long NRs (3.6 aspect ratio)) and applied to detect three different Alzheimer's disease biomarkers: amyloid beta (A $\beta) 1-40, A \beta 1-42$, and $\tau$ protein [31]. The NPs were functionalized with specific antibodies and could detect $A \beta 1-40$, $\mathrm{A} \beta \mathrm{1}-42$, and $\tau$ protein down to $4.9 \mathrm{fM}, 26 \mathrm{fM}$, and $23.6 \mathrm{fM}$, respectively.

A recent study also explored the use of silicon as a substrate. The use of silicon allows for the large-scale fabrication of single-use sensing units, after which the sensor can be retrieved via chemical treatment. For example, Austin Suthanthiraraj et al. fabricated a silver nanostructure by thermally annealing a thin silver film deposited onto a silicon substrate ([65]; Figure 2D). Its shape was spheroidal, and its size ranged between 20 and $80 \mathrm{~nm}$, with spacing ranging from a few tens to a hundred $\mathrm{nm}$. The authors applied this sensor to detect dengue NS1 antigen in whole blood samples. A PDMS channel was created by placing a PDMS slab and its shallow inlet onto an as-fabricated nanostructure. Excess red blood cells and albumin in whole blood was filtered through polyethersulfone membrane on channel inlet because they can often interfere with the detection of analytes in whole blood. Therefore, only plasma 
was retained when blood was injected, and the antigen was captured by the antibody-coated sensing region. This sensor achieved a $\sim 9 \mathrm{~nm} / \mu \mathrm{g} / \mathrm{mL}$ limit of detection.

Large-scale or large-area potential applications of an LSPR-based device were also achieved using copper due to the low cost of this material [66]. One of major drawbacks of using the $\mathrm{Cu}, \mathrm{Cu}$ oxidation, was dramatically reduced by treating the $\mathrm{Cu}$ substrate with acetic acid. This easy-to-fabricate sensor consisted of a $\mathrm{Cu}$ shell/silica NP core structure arranged on an $\mathrm{Au}$ surface. Moreover, it can be manufactured in various formats with high reproducibility and possesses stable optical extinction properties that respond to ambient conditions. This sensor could be potentially used for quantitative and multiplex sensing of target DNAs with a $10 \mathrm{fM}$ $(50 \mathrm{zmol})$ limit of detection, thus enabling pathogen detection from clinical isolates.

The use of periodically ordered arrays is another method for large-area and low-cost sensor fabrication. This not only allows for the control of the size and shape of the sensor components but also provides a reproducible LSPR signal and strong three-dimensional (3D) local field amplification depending on surface geometry, resulting in an enhanced sensitivity. As mentioned above, the array pattern size, shape, and spacing affect the LSPR signal intensity. By taking advantage of the distinct size-, shape-, and spacing-dependent properties of these materials, periodically ordered arrays have been used for the fabrication of flexible, tunable, uniform 3D structure-based platforms [67-72]. For example, a recent study reported the synthesis of an inverted ' $L$ '-shaped nanostructure with a nanograting pattern consisting of an Au-deposited portion on the top and a PDMS layer on the sidewall surface ([54]; Figure 3A). The Au deposited top part was functionalized with a miRNAdetecting locked nucleic acid (LNA) that forms a hairpin structure. In the presence of miRNA and a biotinylated probe, the LNA hairpin structure stretches via base pairing, which is followed by horseradish peroxidase-streptavidin conjugate binding. Afterward, the enzyme-based precipitation of 4-chloronaphthol is induced by the conjugate, resulting in a peak shift of up to $37 \mathrm{~nm}$. This sensor exhibited a miRNA detection limit of $13 \mathrm{fM}$.
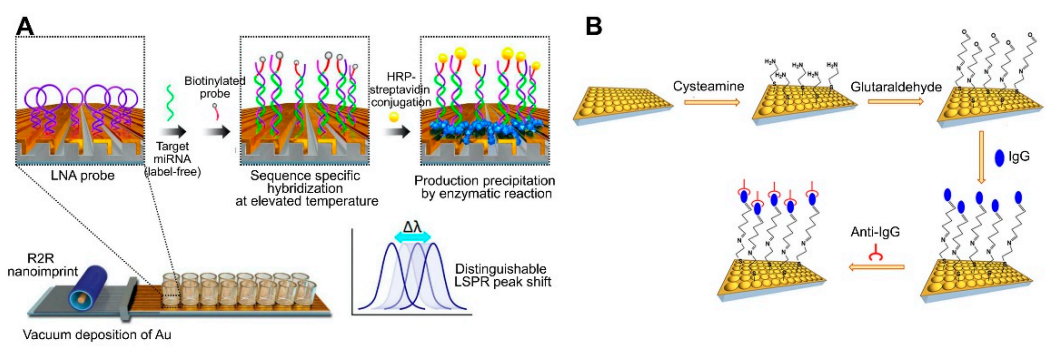

C

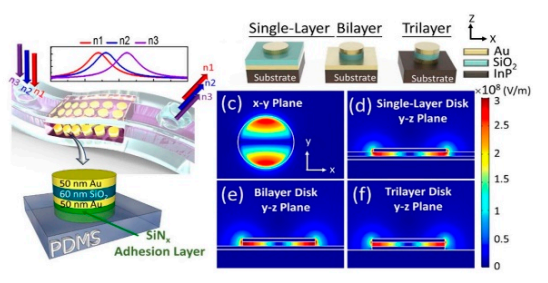

D

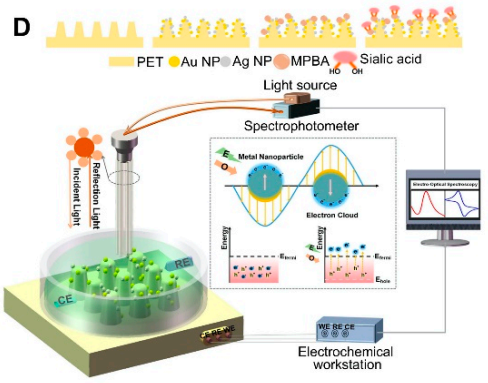

Figure 3. LSPR biosensing strategies based on nanopatterned structures: (A) Detection of miRNA using an inverted ' $\mathrm{L}$-shaped nanostructure with nanograting pattern substrates functionalized with locked nucleic acids (LNAs). Reproduced with permission from [54]; (B) Detection of human IgG using a polystyrene (PS) sphere-deposited glass slide functionalized with antibodies, in which the use of PS of different sizes or shapes results in diverse cup substrates, enabling the modulation of plasmonic response. Reproduced with permission from [50]; (C) Detection of cancer cells attached to a metal-insulator-metal (MIM) integrative PDMS substrate. Reproduced with permission from [51]; (D) Detection of sialic acid by capturing with mercaptophenyl boronic acid (MPBA) via metal-S bond on nanocone shaped polyethylene terephthalate (PET) nanostructures densely covered with Au and AgNPs. Reproduced with permission from [67]. R2R, roll-to-roll; HRP, horseradish peroxidase. 
Uniform and tunable platforms were fabricated using polystyrene spheres (PSs) as pattern generation tools ([50]; Figure 3B). PSs were deposited on glass on which PDMS was initially poured for substrate patterning. Afterward, the PDMS was peeled off to use as the sensor substrate, which was coated with a thin Au film to use the LSPR sensing platform. Different-sized PSs can be used to create PDMS-patterned plasmonic cups with different sizes and spacing between the cups, allowing for the modulation of the plasmonic response of the nanoplatforms, in addition to enhancing the 3D electromagnetic field. Therefore, this method provides a straightforward means to modulate the size/shape of nanostructures by simply changing the size/shape of the deposited nanoparticles, thus yielding nanoplatforms with diverse plasmonic responses. This platform-based sensor was applied to detect human IgG. Anti-human IgG antibodies were attached to an asprepared platform, resulting in a $1.5 \mu \mathrm{g} / \mathrm{mL}$ limit of detection. Arrays of Au nanodisks with uniform and tunable structure were also fabricated on polymethylmethacrylate (PMMA) on glass substrate and applied to detect bacterial cells of Staphylococcus aureus in milk [72]. Varying diameters of Au disks could be achieved by using hole-mask colloidal lithography, in which PS was used as a mask to fabricate arrays of Au disks. Aptamer-functionalized arrays could detect whole $S$. aureus cells down to $10^{3} \mathrm{CFU} / \mathrm{mL}$ within $120 \mathrm{~s}$ without any pretreatment.

Recent advances in flat substrates-based LSPR sensors include the use of flexible nanostructures due to their practicality. More importantly, the main advantage of these sensors is their ability to deliver real-time and POC measurements. To achieve this, LSPR sensors have been developed by incorporating a metal-insulator-metal (MIM) integrative structure on PDMS. MIM structures are outstanding optical absorbers, because their wide angular range of incidence allows for the use of LSPR refractive index sensors under nonplanar surface conditions. A stretchable and highly sensitive detection device based on LSPR sensors with a MIM structure was recently reported. To fabricate this sensor, a MIM-disk LSPR sensor trilayer was first fabricated by sequentially depositing $\mathrm{Au}-\mathrm{SiO}_{2}-\mathrm{Au}$ on an indium(III) phosphide substrate, then embedded onto PDMS, which acted as a transparent, biocompatible, and flexible substrate ([51]; Figure 3C). Enhanced sensitivity and PDMS absorption removal were achieved by changing the embedded depth of the MIM disk on the PDMS. This flexible MIM sensor exhibited a stable sensing performance on nonplanar substrates, with a sensitivity of $3.5 \pm 1.75 \%$ depending on bending curvature.

Another recent trend in flat substrate-based LSPR sensor technology is to combine two different sensing approaches to enhance sensitivity. For example, electrochemical sensing was coupled with an LSPR system to detect sialic acid ([67]; Figure 3D). In this system, the nanostructures served both as electrodes for the electrochemical system and as the optical device for the LSPR sensing system. Electrochemical and LSPR signals are amplified via co-activation. Namely, electrochemical signals activate the electrons surrounding the AuNPs and AgNPs on a nanochip to promote surface plasmon propagation, whereas LSPR concentrates the electrons to enhance the current. The implemented nanostructure consisted of a nanocone-shaped flexible polyethylene terephthalate array, which was fabricated via laser interference lithography and reaction ion etching. The substrate was densely covered with AuNPs, and AgNPs and mercaptophenyl boronic acid were functionalized by capturing sialic acid via metal-S bonds. Using this sensor, sialic acid was detected at concentrations as low as $17 \mu \mathrm{M}$ with a wide linear range of $0.05-5 \mathrm{mM}$.

\subsection{Nanoparticle-Coated Optical Fiber-Based LSPR Sensors}

LSPR technology allows for easy sample handling, does not require highly trained personnel, and can be implemented with small and inexpensive equipment, all of which favors its widespread adoption. The methods for the detection of specific analytes have been recently developed by dipping optical fiber into a sample to be tested [73-75]. The use of optical fibers as LSPR substrates has several advantages, including resistance to electromagnetic interference, chemical passivity, cost reduction, ease of use, and small footprint $[76,77]$. Easy reuse of the optical fiber-based LSPR sensor is also one advantage [75,78-81]. The gen- 
eral approach to reuse is to wash with phosphate buffered saline buffer or sodium dodecyl sulfate solution, and cut and polish the end of the used facet of the optical fiber. Such a simple reuse and recycling process of sensor would facilitate the practical and cost-effective sensing in diverse environmental setting, especially for regions with resource-limited settings. Notably, the combination of optical fiber and plasmonic nanostructures enables the development of miniaturized and portable sensing systems. Optical fiber is available in different configurations, including U-shaped, D-shaped, and tapered, among others [82-84].

As previously mentioned, in the LSPR sensor, the sensitivity is a major concern, and can depend on several factors such as the substrate sensing distance. Electric fields rapidly attenuate as the distance from the colloidal nanoparticles or the pattern substrates increases, resulting in generally short sensing distances of only a few tens of nanometers $[13,21]$. In optical fiber-based sensors, the amplitude of the resulting evanescent wave also falls exponentially as the distance from the fiber core increases because it uses light propagating through a dense fiber core through total internal reflection [85-87]. However, this limitation can be overcome by implementing an unclad core surface. The NPmodified fiber core and receptors mediate the evanescent wave interactions, thereby promoting the change in optical signals. Receptor-functionalized optical fiber/analyte binding events also occur, in which an LSPR peak shift can be induced [74]. Additionally, diverse strategies, such as resonant coupling of plasmons with nanoparticles or resonant molecules, precipitation reactions, and particle growth, have also been developed $[88,89]$. These strategies lead to additional changes in the refractive index of a surrounding nanostructure, resulting in an enhanced sensitivity. However, this approach requires additional operational steps and a secondary target or probe labeling.

Optical fiber-based LSPR sensors have been developed to detect different chemical and biomolecules such as enzymes, cortisol, cancer markers, and bacterial cells [78,79,90-93]. For example, cholesterol was detected by attaching cholesterol oxidase (ChOx) to AuNPcoated fiber via an adhesive layer of (3-mercaptopropyl) trimethoxysilane. The $\mathrm{ChOx}$ enzyme specifically oxidizes cholesterol in the presence of oxygen, producing $\mathrm{H}_{2} \mathrm{O}_{2}$ and cholestenone. The level of $\mathrm{H}_{2} \mathrm{O}_{2}$ modulates the refractive index at the surface of the AuNPs and changes the reflectance intensity. AuNP-coated fiber has also been sequentially treated with MUA (carboxyl group)-EDC/NHS-ChOx ([85]; Figure 4A). Another study reported the detection of OTA using aptamer-modified GNRs immobilized on an optical fiber core surface ([74]; Figure 4B). For in situ detection of OTA based on optical fiber as the LSPR sensing platform, the sensing probe was dipped into a sample solution, after which the LSPR peak shift was monitored. OTA-specific aptamers were immobilized on GNRs, which were deposited onto thiol-functionalized glass. The specific binding of aptamer and OTA leads to a conformational change in the aptamer, thus increasing the local refractive index surrounding the GNR. This sensor could detect OTA concentrations as low as $12 \mathrm{pM}$ with a 10 to $100 \mathrm{pM}$ dynamic range. Another study developed an optical fiber-based sensor for the detection of $\mathrm{Hg}^{2+}$ ([75]; Figure 4C). The detection of $\mathrm{Hg}^{2+}$ relies on the T- $\mathrm{Hg}^{2+}-\mathrm{T}$ structure and plasmonic coupling effect. The sidewall of the LSPR fiber was firstly coated with an Au nanosphere monolayer (NSM) and then functionalized with a thiolated DNA probe (DNAP) via Au-S bonds. When the sample contained $\mathrm{Hg}^{2+}$, another DNA (DNAT) whose sequence was complementary to the probe DNA could bind with the probe via $\mathrm{T}-\mathrm{Hg}^{2+}-\mathrm{T}$ base match, resulting in near field coupling enhancement. When the DNAT was attached to another small-sized Au NP (AuNSL), the DNAP:DNAT duplex induced a near field coupling effect due to the close proximity between AuNSM and AuNSL, which increases the refractive index at the AuNSM surface and causes a wavelength red shift, thus enhancing sensitivity. This sensor could detect $\mathrm{Hg}^{2+}$ at concentrations as low as $0.7 \mathrm{nM}$ with a $1-50 \mathrm{nM}$ dynamic range. 
A

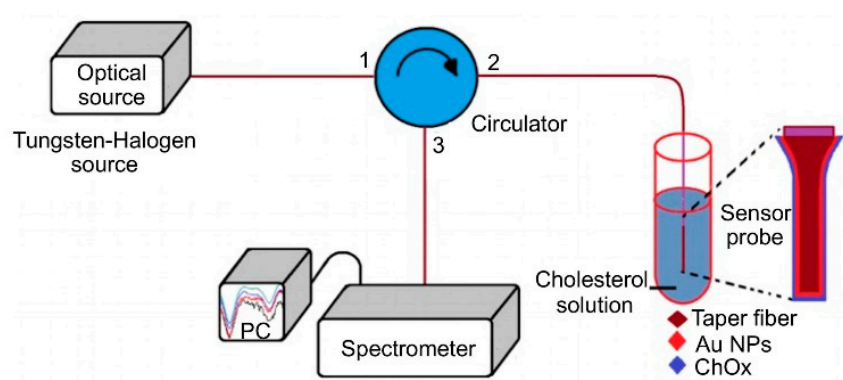

B
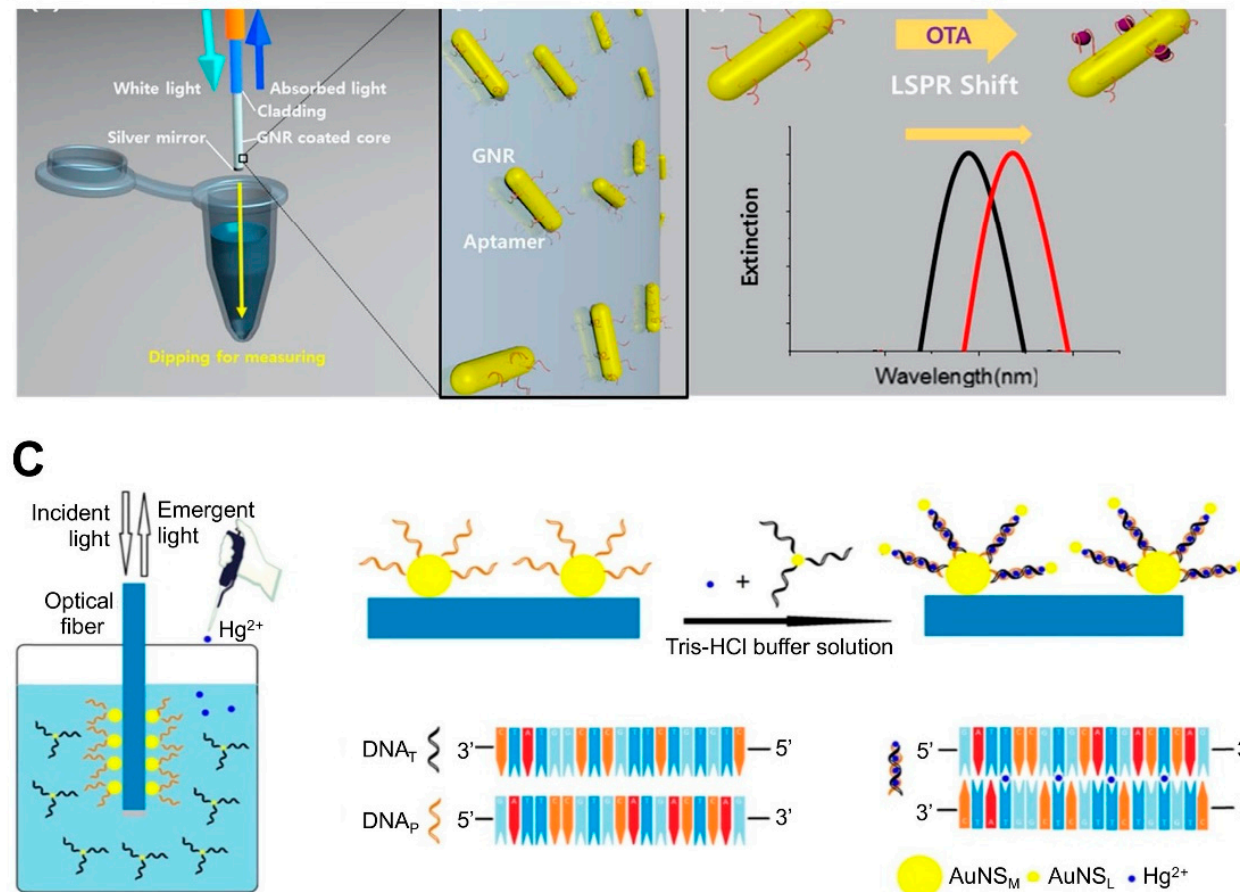

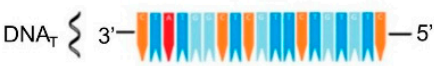

$\mathrm{DNA}_{\mathrm{p}} \leq 5^{\prime}-\|\|,,\|\|,,\|\|,, \|, \mid-3^{\prime}$

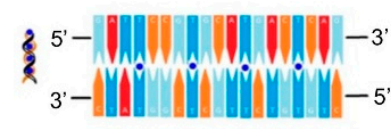

$\mathrm{AuNS}_{\mathrm{M}} \odot \mathrm{AuNS}_{\mathrm{L}} \cdot \mathrm{Hg}^{2+}$

Figure 4. LSPR biosensing strategies based on nanoparticle (NP)-coated optical fibers: (A) Detection of cholesterol using cholesterol oxidase attached to an AuNP-immobilized fiber. Reproduced with permission from [85]; (B) Detection of ochratoxin A (OTA) using aptamer-modified gold nanorods (GNRs) immobilized on an optical fiber. Reproduced with permission from [74]; (C) Detection of $\mathrm{Hg}^{2+}$ using optical fiber functionalized with Au nanospheres (AuNS) and a thiolated DNA probe. Reproduced with permission from [75].

Recently, LSPR sensors coupled with different mode optical fibers were developed and applied to detect whole bacterial cells $[78,91]$. One example of these sensors exhibits two physical contact fiber structures: single mode fiber (SMF) and multi-core fiber (MCF). MCF structure exhibits high sensitivity to small RI variations due to intercoupling between cores of MCF and compact architecture. MCF has also low connection loss with SMF. This sensor was immobilized with DNA aptamer and could detect Shigella sonnei down to $1.56 \mathrm{CFU} / \mathrm{mL}$ within $5 \mathrm{~min}$ [91]. Another example is the tapered SMF-no core fiber-SMF structure. This fiber was functionalized with $\operatorname{IgG}$ antibody and could detect $S$. aureus with $\mathrm{LoD}$ of $3.1 \mathrm{CFU} / \mathrm{mL}[78]$. 


\section{Conclusions and Future Perspectives}

Biosensing assays will become increasingly important in the near future, and will likely have a strong impact in the fields of clinical research, forensics, biodefense, food safety, animal health care, and pathology. However, the rapid, accurate, and multiplexed identification of biomarkers or causative agents in a variety of settings in a low-cost manner remains a major challenge of this field. The repeatability and reproducibility of sensing outcomes are also the important characteristics for measuring the precision of sensors. For repeatability, a range of values distributed relative to the actual value should be minimized at the same location, measurements, procedure, observer, and the measuring instrument within a short period of time. For reproducibility, the outputs from the experiments conducted by different individuals at different locations with different instruments should be consistent. There is currently an ever-increasing demand for disease diagnosis and environmental monitoring solutions, which highlights the need for further biosensing device development.

Future LSPR biosensors will likely incorporate novel nanomaterials, receptors, and sensing devices. Current research trends have established a departure from single-mode sensing devices in favor of multimodal biosensors, which incorporate a wide range of sensing approaches that are now being tested for molecule-detection applications [67]. These approaches have also been combined with microfluidic devices $[51,61,94,95]$ and complementary metal-oxide-semiconductor (CMOS) devices $[96,97]$ for the continuous and real-time detection of biomolecules. Additionally, new insights into the design and screening of synthetic receptors have been obtained using powerful selection methods such as systematic evolution of ligands by exponential enrichment (SELEX) and its alternatives [98-100], in addition to click chemistry [101,102], all of which will likely result in more sensitive and specific sensing of diverse biomarkers. These breakthroughs and innovations will undoubtedly lead to the emergence and discovery of new technologies and materials for disease diagnosis and environmental monitoring in the near future.

One important research topic regarding the detection of biomolecules is to improve the limit of detection without off-target effects. Modulating the LSPR frequency can affect sensitivity. Most LSPR biosensors focus on the use of metallic particles or nanostructures as a sensing platform; however, the metallic materials currently used are inherently limited. LSPR frequency control could be better implemented in semiconductor-based nanocrystals than in their metallic counterparts. Therefore, a wider range of biomolecules could be detected by broadening the sensing spectrum from the deep ultraviolet range (for the detection of nucleic acids and proteins) to the far infrared (for the detection of cells and tissues). A related study reported that the LSPR frequency varied from 1600 to $2200 \mathrm{~nm}$ by controlling the concentration of a tin dopant [103], and tungsten oxide nanoparticles exhibited an optical absorption from 900 to $1100 \mathrm{~nm}$ by doping additional oxygen atoms into their crystal structure to modify the carrier density [104]. However, additional efforts are required to discover novel plasmonic materials for the development of new platforms to detect diverse molecules. 
Therefore, future studies should focus on the development of novel methods for surface modification and bio-conjugation on plasmonic materials. For instance, innovative functionalization methods can be achieved via click chemistry and using substrate-specific peptides or proteins. Click chemistry-based bioconjugation is a simple and fast procedure that enables process control and enhances chemo-selectivity [105]. Moreover, this approach does not perturb biomolecule activity due to the small size of its components [106]. For example, a silver enhancement signal amplification strategy can be employed to detect $\mathrm{Cu}$ (II) ions in aqueous solutions with high sensitivity. Based on a $\mathrm{Cu}(\mathrm{I})$-catalyzed 'click' reaction between azide-functionalized AuNPs and an alkyne-modified glass slide, this method enables $\mathrm{Cu}$ (II) detection down to $62 \mathrm{pM}$. Combined with click chemistry, Qdots could be also used as fluorescent probes to visualize and track individual viral particles. Using this clickable surface modification strategy, multidentate-imidazole ligands were synthesized and living viruses could be attached to the Qdots. More importantly, the resulting virusattached Qdots did not affect the viral infection [107]. Using the same strategy, Qdots were functionalized with avian influenza H5N1 pseudotype virus (H5N1p), and this conjugate exhibited bright and sustained fluorescent signals in mouse lung tissues, allowing for the noninvasive visualization of respiratory viral infections in real time [108]. Another surface modification strategy is to use substrate-specific peptides or proteins. Representative examples include metal-binding peptides, which act as a linker to modify the surface of metals such as Ni-Ti, Pt-W, Co-Cr, FeO, and Au [109-111]. To modify the metallic surface, these peptides or proteins must have a high affinity for metal, which affects the surface density of the grafted polymers, in addition to the biosensor sensitivity. The small size of these peptides or protein motifs allows them to form compact surface coatings, and therefore the desired function is minimally disrupted. Biocompatibility could also be an important factor to improve the surface properties of biosensors, particularly for medical purposes. Such peptides or protein motifs can be designed and selected using various methods such as phage display or cell surface display technology [111]. Recent advances have led to the development of machine learning-based computational prediction and computational approaches, which allow for the de novo design and redesign of metal-binding sites on proteins $[112,113]$. These strategies will surely enable the fabrication of surface platforms consisting of diverse plasmonic materials with specific and sensitive sensing performance, and the development of controlled and tunable LSPR technology. In addition, for commercialization of LSPR sensors, many practical assets, such as miniaturization, flexibility, and remote control, are desired. 
Table 1. Examples of nanostructure-based LSPR biosensors for the detection of various molecules ${ }^{\mathrm{a}}$.

\begin{tabular}{|c|c|c|c|c|c|c|c|c|}
\hline Classification & Substrate & Receptor & Analyte & Linear Range, LOD & Assay Time & $\begin{array}{c}\text { Real } \\
\text { Sample }\end{array}$ & Features & Reference \\
\hline \multirow{4}{*}{$\begin{array}{l}\text { Solution } \\
\text { phase-based } \\
\text { nanoparticle }\end{array}$} & $\begin{array}{l}\text { AuNP-based } \\
\text { core-satellite } \\
\text { structure }\end{array}$ & $\begin{array}{c}\mathrm{Hg}^{2+} \text { incorporating } \\
\text { DNA duplex }\end{array}$ & Glutathione (GSH) & $0.1 \mu \mathrm{M}$ & $30 \mathrm{~min}$ & ND & $\begin{array}{l}\text { Use of property of GSH } \\
\text { with high affinity for } \mathrm{Hg}^{2+} \text {. } \\
\text { Caused a blue shift in the } \\
\text { LSPR peak by AuNP } \\
\text { structural collapse upon } \\
\text { exposure to GSH. }\end{array}$ & [36]; Figure 1A \\
\hline & $\begin{array}{c}\text { CdSe/ZnSeS } \\
\text { core/alloyed shell } \\
\text { Quantum dot (Qdot) }\end{array}$ & $\begin{array}{l}\text { DNA (molecular } \\
\text { beacon) }\end{array}$ & Dengue virus & 20 copies per $\mathrm{mL}$ & ND & ND & $\begin{array}{l}\text { Quencher use: Change in } \\
\text { PL Qdot depending on the } \\
\text { presence/absence of target } \\
\text { DNA in the sample. } \\
\text { Conjugation of Qdots and } \\
\text { AuNPs: boosting PL of } \\
\text { Qdots by LSPR } \\
\text { from AuNPs. }\end{array}$ & [7]; Figure 1B \\
\hline & $\mathrm{AuNP}$ & None & Melamine & $\begin{array}{c}0 \mu \mathrm{M} \text { to } 0.9 \mu \mathrm{M} \\
33 \mathrm{nM}\end{array}$ & ND & Liquid milk & $\begin{array}{l}\text { Use of unmodified AuNPs } \\
\text { without the need for a } \\
\text { receptor due to the } \\
\text { interaction of amine groups } \\
\text { of melamine and AuNPs. } \\
\text { Recovery rate of } \\
99.2 \sim 111 \% \text {. }\end{array}$ & [114] \\
\hline & AuNP & Aptamer & Ochratoxin A (OTA) & $0.0316-316 \mathrm{ng} / \mathrm{mL}$ & $>15 \min$ & Spiked corn & $\begin{array}{l}\text { Use of color change based } \\
\text { on AuNPs aggregation } \\
\text { caused by competition } \\
\text { between aptamer-bound } \\
\text { Au NPs and OTA. } \\
\text { Use of double calibration } \\
\text { curve method to widen the } \\
\text { detection range. }\end{array}$ & [40] \\
\hline $\begin{array}{l}\text { NP-deposited flat } \\
\text { substrate }\end{array}$ & $\begin{array}{l}\text { AuNP on the } \\
\text { glass slide }\end{array}$ & Aptamer & $\begin{array}{l}\text { Salmonella } \\
\text { typhimurium }\end{array}$ & $\begin{array}{c}1.0 \times 10^{4} \mathrm{CFU} / \mathrm{mL} \\
10^{4} \mathrm{CFU} / \mathrm{mL}\end{array}$ & $>30-35$ min & Pork meat & $\begin{array}{l}\text { Fabrication of } \\
\text { AuNP-coated transparent } \\
\text { glass slide via a simple } \\
\text { dipping adsorption } \\
\text { method } \\
\text { Use of APTES-immobilized } \\
\text { glass slide to attach AuNPs }\end{array}$ & [57]; Figure 2A \\
\hline
\end{tabular}


Table 1. Cont.

\begin{tabular}{|c|c|c|c|c|c|c|c|c|}
\hline Classification & Substrate & Receptor & Analyte & Linear Range, LOD & Assay Time & $\begin{array}{l}\text { Real } \\
\text { Sample }\end{array}$ & Features & Reference \\
\hline \multirow{6}{*}{$\begin{array}{l}\text { Solid-based } \\
\text { nanopatterned } \\
\text { flatform }\end{array}$} & $\begin{array}{l}\text { AuNP on the } \\
\text { glass slide }\end{array}$ & Anti-CRP & $\begin{array}{l}\text { C-reactive protein } \\
\text { (CRP) }\end{array}$ & $\begin{array}{c}0.01-10 \mu \mathrm{g} / \mathrm{mL} \\
11.28 \mathrm{ng} / \mathrm{mL}\end{array}$ & ND & ND & $\begin{array}{l}\text { Fabrication of a } \\
\text { plasmonically active strip } \\
\text { by depositing AuNPs on } \\
\text { an APTES-immobilized } \\
\text { glass slide. } \\
\text { Use of cysteine-protein G } \\
\text { to attach a receptor. }\end{array}$ & {$[60]$} \\
\hline & Au nanorod (GNR) & Aptamer & 25-hydroxyvitamin $D_{3}$ & $\begin{array}{l}0.1-10^{5} \mathrm{ng} / \mathrm{mL} \\
0.1 \mathrm{ng} / \mathrm{mL}\end{array}$ & ND & $\begin{array}{l}\text { Human serum } \\
\text { albumin sample }\end{array}$ & $\begin{array}{l}\text { Use of citrate as a stabilizer } \\
\text { of GNR: improving } \\
\text { LSPR signal. }\end{array}$ & [62] \\
\hline & $\begin{array}{l}\text { Heteroassembled } \\
\text { AuNPs }\end{array}$ & Antibody & $\begin{array}{c}\text { Hepatitis B } \\
\text { surface antigen }\end{array}$ & $\begin{array}{l}100 \mathrm{fg} / \mathrm{mL}- \\
10 \mathrm{ng} / \mathrm{mL} \\
10 \mathrm{pg} / \mathrm{mL}\end{array}$ & $>10-15 \min$ & Human serum & $\begin{array}{l}\text { Use of a multi-layered } \\
\text { plasmonic structure } \\
\text { by linking } \\
\text { different-sized AuNPs. }\end{array}$ & [59]; Figure 2B \\
\hline & GNR on glass slide & Aptamer & $\begin{array}{l}\text { OTA, AFB1, ATP, } \\
\text { and } \mathrm{K}^{+}\end{array}$ & $\begin{array}{c}0.56 \mathrm{pM} \text { for OTA, } \\
0.63 \mathrm{pM} \text { for AFB1, } \\
0.87 \mathrm{pM} \text { for ATP, } \\
1.05 \mathrm{pM} \text { for } \mathrm{K}^{+}\end{array}$ & $30 \mathrm{~min}$ & $\begin{array}{c}\text { Ground corn } \\
\text { powder, Escherichia } \\
\text { coli, human serum }\end{array}$ & $\begin{array}{l}\text { Use of berberine as an } \\
\text { LSPR signal enhancer, } \\
\text { which incorporates into the } \\
\text { G-quadruplex structure } \\
\text { that forms when the } \\
\text { aptamer binds to the } \\
\text { analyte and undergoes a } \\
\text { conformational change. }\end{array}$ & [61] \\
\hline & GNR on glass slide & Aptamer & Saxitoxin & $\begin{array}{c}5-10,000 \mu \mathrm{g} / \mathrm{L} \\
2.46 \mu \mathrm{g} / \mathrm{L}\end{array}$ & $30 \mathrm{~min}$ & Mussel sample & $\begin{array}{l}\text { Use of newly developed } \\
\text { aptamers by implementing } \\
\text { the graphene oxide } \\
\text { (GOx)-SELEX method. } \\
\text { Recovery rate of } \\
96.13 \sim 116.05 \% \text {. }\end{array}$ & [115] \\
\hline & AuNP on glass slide & Antibody & $\begin{array}{l}\text { Alzheimer's disease } \\
\text { biomarkers }\end{array}$ & $\begin{array}{c}4.9 \mathrm{fM} \text { for amyloid } \\
\text { beta }(\mathrm{A} \beta) 1-40,26 \mathrm{fM} \\
\text { for A } \beta 1-42 \\
\text { and } 23.6 \mathrm{fM} \text { for } \\
\tau \text { protein }\end{array}$ & ND & Human plasma & $\begin{array}{l}\text { Multiplex detection using } \\
\text { nanoparticles with } \\
\text { different sizes and shapes, } \\
\text { each of which was } \\
\text { functionalized with } \\
\text { various marker-specific } \\
\text { antibodies. }\end{array}$ & [31] \\
\hline
\end{tabular}


Table 1. Cont.

\begin{tabular}{|c|c|c|c|c|c|c|c|c|}
\hline Classification & Substrate & Receptor & Analyte & Linear Range, LOD & Assay Time & $\begin{array}{c}\text { Real } \\
\text { Sample }\end{array}$ & Features & Reference \\
\hline & $\begin{array}{l}\text { AuNP-coated } \\
\text { glass slide }\end{array}$ & DNA & $\begin{array}{l}\text { MicroRNAs } \\
\text { (miRNAs) }\end{array}$ & $\begin{array}{c}5 \mathrm{pM} \text { to } 10 \mathrm{nM} \\
2.45 \mathrm{pM}\end{array}$ & ND & $\begin{array}{c}\text { Mouse Sample } \\
\text { (urine and plasma) }\end{array}$ & $\begin{array}{l}\text { Incorporation of LSPR } \\
\text { signal amplification } \\
\text { strategy using a } \\
\text { duplex-specific } \\
\text { nuclease-mediated target } \\
\text { recycling reaction. } \\
\text { Use of Au NP coated with } \\
\text { tannic acid (a hydrophilic } \\
\text { polyphenol compound) } \\
\text { that can interact with the } \\
\text { phosphate backbone of } \\
\text { DNA, thereby enhancing } \\
\text { LSPR signal. }\end{array}$ & [63]; Figure 2C \\
\hline & $\begin{array}{l}\text { Ag nanoprism } \\
\text { on glass }\end{array}$ & DNA probe & Bacterial DNA & $\begin{array}{c}5 \mathrm{fg} / \mu \mathrm{L} \text { of } E . \text { coli } \\
\text { DNA, } 300 \mathrm{cfu} / \mathrm{mL}\end{array}$ & $>15$ min & ND & $\begin{array}{l}\text { Fabrication of an LSPR } \\
\text { platform by depositing Ag } \\
\text { nanoprisms on } \\
\text { poly-L-lysine-coated glass. } \\
\text { Combined system } \\
\text { consisting of microfluidic } \\
\text { on-chip PCR and LSPRi } \\
\text { using a digital micromirror } \\
\text { device Real-time detection } \\
\text { using a qPCR system. }\end{array}$ & [116] \\
\hline & $\begin{array}{l}\text { Ag nanocolumn on } \\
\text { glass slide }\end{array}$ & Polymyxin B & $\begin{array}{l}\text { Lipopolysaccharide } \\
\text { endotoxin }\end{array}$ & $340 \mathrm{pg} / \mathrm{mL}$ & ND & ND & $\begin{array}{l}\text { Use of } \\
\text { 3-mercaptopropionic acid } \\
\text { to stabilize the Ag } \\
\text { nanocolumn against } \\
\text { oxidation and nanoparticle } \\
\text { detachment in } \\
\text { aqueous environments. }\end{array}$ & [117] \\
\hline & $\begin{array}{l}\text { Ag nanocolumn on } \\
\text { glass slide }\end{array}$ & Antibody & $\begin{array}{l}\text { Prostate-Specific } \\
\text { Antigen }\end{array}$ & $850 \mathrm{pg} / \mathrm{mL}$ & ND & ND & $\begin{array}{l}\text { Use of } \\
\text { 11-mercaptoundecanoic } \\
\text { acid as a stabilizer of the } \\
\text { Ag nanocolumn. }\end{array}$ & [118] \\
\hline
\end{tabular}


Table 1. Cont.

\begin{tabular}{|c|c|c|c|c|c|c|c|c|}
\hline Classification & Substrate & Receptor & Analyte & Linear Range, LOD & Assay Time & $\begin{array}{c}\text { Real } \\
\text { Sample }\end{array}$ & Features & Reference \\
\hline & $\begin{array}{l}\text { Ag nanostructure on } \\
\text { silicon substrate }\end{array}$ & $\begin{array}{l}\text { NS1 antigen-specific } \\
\text { antibody (IgG) }\end{array}$ & $\begin{array}{l}\text { NS1 antigen of } \\
\text { dengue virus }\end{array}$ & $0.06 \mu \mathrm{g} / \mathrm{mL}$ & $>30 \mathrm{~min}$ & Whole blood & $\begin{array}{l}\text { Fabrication of } \\
\text { nanostructures by E-beam } \\
\text { evaporation and thermal } \\
\text { annealing of thin } \\
\text { silver film. } \\
\text { Integration of } \\
\text { polyethersulfone } \\
\text { membrane filter at the inlet } \\
\text { of a biosensor for plasma } \\
\text { separation. } \\
\text { Small sample volume } \\
\text { requirements }(10 \mu \mathrm{L} \text { of } \\
\text { whole blood sample). }\end{array}$ & [65]; Figure 2D \\
\hline & $\begin{array}{l}\text { Nickel-doped } \\
\text { graphene (NDG) on } \\
\text { self-assembled gold } \\
\text { nanoislands } \\
\text { (SAM AuNI) }\end{array}$ & GOx & $\begin{array}{l}\text { 3-nitro-L-tyrosine } \\
\text { (3-NT) }\end{array}$ & $\begin{array}{l}0.1 \mathrm{pg} / \mathrm{mL}- \\
10 \mathrm{ng} / \mathrm{mL} \\
0.13 \mathrm{pg} / \mathrm{mL}\end{array}$ & ND & Human serum & $\begin{array}{l}\text { Fabrication of imprinted } \\
\text { nanostructure by thermal } \\
\text { annealing of Au, followed } \\
\text { by spin coating and } \\
\text { thermal annealing of } \\
\text { graphene and nickel. } \\
\text { Use of strong energy } \\
\text { adsorption by } \pi-\pi \text { stacking } \\
\text { interaction between } \mathrm{NO}_{2} \\
\text { site of 3-NT and NDG }\end{array}$ & [119] \\
\hline & $\begin{array}{l}\text { Poly(mPD-co-ASA) } \\
\text { on SAM-AuNI }\end{array}$ & $\begin{array}{c}\text { Poly(m- } \\
\text { phenylenediamine- } \\
\text { co-ani-line-2- } \\
\text { sulfonic acid) } \\
\text { (Poly(mPD-co- } \\
\text { ASA }) \text { ) }\end{array}$ & $\mathrm{Pb}^{2+}$ & $\begin{array}{c}0.011 \mathrm{ppb}-5 \mathrm{ppm} \\
0.011 \mathrm{ppb}\end{array}$ & ND & Drinking water & $\begin{array}{l}\text { Use of poly(mPD-co-ASA) } \\
\text { as a linker with AuNI and } \\
\mathrm{Pb}^{2+} \text { receptor. }\end{array}$ & [120] \\
\hline & SAM-AuNIs & Anti-CD7 antibody & Exosome & $\begin{array}{c}0.194-100 \mu \mathrm{g} / \mathrm{mL} \\
0.194 \mu \mathrm{g} / \mathrm{mL}\end{array}$ & ND & Serum, urine & $\begin{array}{l}\text { Use of exosome properties } \\
\text { with high affinity for AuNI } \\
\text { due to its negative zeta } \\
\text { potential value }\end{array}$ & [121] \\
\hline & SAM-AuNIs & Anti-IgG & Human IgG antigen & $\begin{array}{c}1 \mathrm{pM}-100 \mathrm{pM}, \\
1.188 \mathrm{pM}\end{array}$ & ND & Serum & & [122] \\
\hline
\end{tabular}


Table 1. Cont.

\begin{tabular}{|c|c|c|c|c|c|c|c|c|}
\hline \multirow[t]{2}{*}{ Classification } & Substrate & Receptor & Analyte & Linear Range, LOD & Assay Time & $\begin{array}{c}\text { Real } \\
\text { Sample }\end{array}$ & Features & Reference \\
\hline & $\begin{array}{l}\text { 3D Au nanocups } \\
\text { platform on poly- } \\
\text { dimethylsiloxane } \\
\text { (PDMS) surface }\end{array}$ & Antibody & Human IgG & $1.5 \mu \mathrm{g} / \mathrm{mL}$ & ND & ND & $\begin{array}{l}\text { Fabrication of imprinted } \\
\text { nanostructures by } \\
\text { deposition of a polystyrene } \\
\text { (PS) monolayer on glass, } \\
\text { pouring PDMS on a PS } \\
\text { layer, peeling off the PDMS } \\
\text { film, and coating the PDMS } \\
\text { substrate with an Au film. } \\
\text { Fabrication of uniform and } \\
\text { tunable platform by } \\
\text { changing the PS size. }\end{array}$ & [50]; Figure 3B \\
\hline & $\begin{array}{c}\text { Metal-insulator- } \\
\text { metal (MIM) } \\
\text { nanodisks on PDMS }\end{array}$ & None & $\begin{array}{c}\text { Cancer cell } \\
\text { (adherent cell) }\end{array}$ & NA & ND & ND & 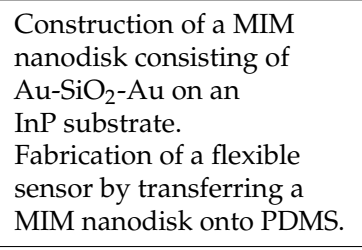 & [51]; Figure 3C \\
\hline & $\begin{array}{l}\mathrm{Au} \text { and AgNPs on } \\
\text { PET cone } \\
\text { array structure }\end{array}$ & $\begin{array}{l}\text { Mercaptophenyl } \\
\text { boronic acid }\end{array}$ & Sialic acid & $0.05-5 \mathrm{mM}, 17 \mu \mathrm{M}$ & ND & ND & $\begin{array}{l}\text { Fabrication of core array } \\
\text { nanostructures by } \\
\text { depositing Au and AgNPs } \\
\text { on (poly)ethylene } \\
\text { terephthalate (PET). } \\
\text { Combined system } \\
\text { consisting of LSPR and an } \\
\text { electrochemical } \\
\text { sensing system. }\end{array}$ & [67]; Figure 3D \\
\hline & $\begin{array}{c}\text { Au-deposited 3D } \\
\text { polyurethane } \\
\text { acrylate (PUA) } \\
\text { nanostructure }\end{array}$ & Locked nucleic acid & miRNAs & $\begin{array}{c}13 \mathrm{fM}(2.6 \text { attomole } \\
\text { in } 200 \mu \mathrm{L})\end{array}$ & ND & $\begin{array}{l}\text { Primary cancer } \\
\text { cell lines }\end{array}$ & $\begin{array}{l}\text { Fabrication of 3D } \\
\text { plasmonic nanostructure } \\
\text { consisting of roll-to-roll } \\
\text { nanoimprint } \\
\text { lithography-used PUA } \\
\text { nanograting pattern, } \\
\text { followed by Au deposition. } \\
\text { Detection of miRNA } \\
\text { single-base mismatches } \\
\text { down to the attomole level } \\
\text { by incorporating a biotin- } \\
\text { streptavidin-horseradish } \\
\text { precipitation reaction. }\end{array}$ & [54]; Figure 3A \\
\hline
\end{tabular}


Table 1. Cont.

\begin{tabular}{|c|c|c|c|c|c|c|c|c|}
\hline Classification & Substrate & Receptor & Analyte & Linear Range, LOD & Assay Time & $\begin{array}{c}\text { Real } \\
\text { Sample }\end{array}$ & Features & Reference \\
\hline & $\begin{array}{l}\text { Au nano-ellipsoid } \\
\text { array on } \\
\text { quartz substrate }\end{array}$ & Anti-CD63 antibody & Exosome & $1 \mathrm{ng} / \mathrm{mL}$ & $<4 \mathrm{~h}$ & ND & $\begin{array}{l}\text { Fabrication of } \\
\text { nanostructures via } \\
\text { AAO-templated Au } \\
\text { deposition on a } \\
\text { quartz substrate. } \\
\text { Integration of LSPR and } \\
\text { microfluidic systems. }\end{array}$ & [123] \\
\hline & $\begin{array}{l}\text { Au nanopillars on } \\
\text { quartz coverslips }\end{array}$ & Anti-CD63 antibody & Exosome & ND & ND & $\begin{array}{l}\text { MCF7 breastadeno- } \\
\text { carcinoma cells }\end{array}$ & $\begin{array}{l}\text { Fabrication of Au } \\
\text { nanopillar array by } \\
\text { electron beam lithography. } \\
\text { Enabled multiplexed } \\
\text { measurement using LSPRi. }\end{array}$ & [52] \\
\hline & Au nanopillar & $\begin{array}{l}\text { Mercaptobenzoic } \\
\text { acid }\end{array}$ & BSA & $234 \mathrm{pM}$ & ND & ND & $\begin{array}{l}\text { Working in the visible and } \\
\text { infrared region by } \\
\text { changing the patterned } \\
\text { shapes and } \\
\text { interpillar distances. }\end{array}$ & [53] \\
\hline & $\begin{array}{l}\text { Au film on } \\
\text { glass wafer }\end{array}$ & $\begin{array}{c}\text { Anti-IgG, } \\
\text { anti-TNF- } \alpha, \\
\text { anti-CRP antibody }\end{array}$ & IgG, TNF- $\alpha$, CRP & $\begin{array}{l}10 \mathrm{ng} / \mathrm{mL} \mathrm{IgG} \\
10 \mathrm{ng} / \mathrm{mL} \text { CRP }\end{array}$ & $3.5 \mathrm{~h}$ & ND & $\begin{array}{l}\text { Fabrication of } \\
\text { nanostructure using } \\
\text { physical vapor evaporation } \\
\text { followed by a rapid } \\
\text { thermal } \\
\text { annealing treatment. }\end{array}$ & [124] \\
\hline & $\begin{array}{l}\text { Polymethylmethacrylate } \\
\text { (PMMA) on } \\
\text { glass substrate }\end{array}$ & Aptamer & Staphylococcus aureus & $10^{3} \mathrm{CFU} / \mathrm{mL}$ & $120 \mathrm{~s}$ & Milk & $\begin{array}{l}\text { Fabrication of arrays of Au } \\
\text { nanodisks on } \\
\text { PMMA-treated glass } \\
\text { substrate by using } \\
\text { hole-mask colloidal } \\
\text { lithography. } \\
\text { Optimization of disk } \\
\text { structure by varying } \\
\text { diameter: improving } \\
\text { LSPR signal. }\end{array}$ & [72] \\
\hline $\begin{array}{l}\text { NP-coated optic } \\
\text { fiber-based platform }\end{array}$ & $\begin{array}{l}\text { AuNPs-immobilized } \\
\text { taperfiber }\end{array}$ & $\begin{array}{l}\text { Cholesterol oxidase } \\
\text { (ChOx) }\end{array}$ & Cholesterol & $\begin{array}{c}10 \mathrm{nM}-1 \mu \mathrm{M} \\
53.1 \mathrm{nM}\end{array}$ & ND & ND & $\begin{array}{l}\text { Fabrication of sensing } \\
\text { component by } \\
\text { sequentially coating } \\
\text { MUA-EDC/NHS-ChOx on } \\
\text { AuNPs-immobilized fiber. }\end{array}$ & [85]; Figure 4A \\
\hline
\end{tabular}


Table 1. Cont.

\begin{tabular}{|c|c|c|c|c|c|c|c|c|}
\hline Classification & Substrate & Receptor & Analyte & Linear Range, LOD & Assay Time & $\begin{array}{c}\text { Real } \\
\text { Sample }\end{array}$ & Features & Reference \\
\hline & $\begin{array}{l}\text { GNRs immobilized } \\
\text { on the optical fiber } \\
\text { core surface }\end{array}$ & Aptamer & OTA & $\begin{array}{c}10 \mathrm{pM} \text { to } 100 \mathrm{nM}, \\
12.0 \mathrm{pM}\end{array}$ & ND & Grape juice & $\begin{array}{l}\text { Detection by simply } \\
\text { dipping an optical fiber } \\
\text { into a sample solution, } \\
\text { allowing in situ detection. }\end{array}$ & $\begin{array}{c}{[74] ;} \\
\text { Figure 4B }\end{array}$ \\
\hline & $\begin{array}{l}\text { AuNPs-coated } \\
\text { optical fiber }\end{array}$ & $\begin{array}{l}\text { Anti-transferrin, } \\
\text { protein A }\end{array}$ & $\begin{array}{l}\text { Transferrin, } \\
\text { protein IgG }\end{array}$ & ND & ND & ND & $\begin{array}{l}\text { Combined system } \\
\text { consisting of capillary } \\
\text { LSPR sensors and metal- } \\
\text { oxide-semiconductor } \\
\text { image sensors. } \\
\text { Use of AuNPs-coated } \\
\text { capillary as a microfluidic } \\
\text { channel and } \\
\text { sensing surface. } \\
\text { Multiple detection for high } \\
\text { throughput screening of } \\
\text { biomolecular interactions }\end{array}$ & [96] \\
\hline & $\begin{array}{l}\text { Optical fiber with } \\
\text { copper oxide } \\
\text { nanoflower } \\
\text { (CuO-NF) and } \mathrm{Au} \\
\text { NPs-coated GOx } \\
\text { structure }\end{array}$ & $\begin{array}{l}\text { 2-deoxy-D-glucose } \\
\text { (2-DG) }\end{array}$ & Cancer cell & $\begin{array}{c}1 \times 10^{2}-1 \times 10^{6} \text { cells } / \mathrm{mL} \\
2-10 \text { cells } / \mathrm{mL}\end{array}$ & ND & ND & $\begin{array}{l}\text { Use of multi-core fiber } \\
\text { structure. } \\
\text { Coating of optical fiber } \\
\text { with GOx and CuO-NF: } \\
\text { increasing surface area and } \\
\text { adsorption capability. } \\
\text { Discrimination of cancer } \\
\text { cells using 2-DG that binds } \\
\text { to GULP receptor: the } \\
\text { presence of more GULP } \\
\text { receptors on cancer cell, } \\
\text { inducing a peak shift. } \\
\text { Reusable through washing } \\
\text { with PBS. }\end{array}$ & [79] \\
\hline & $\begin{array}{l}\text { AuNPs-coated } \\
\text { optical fiber }\end{array}$ & Aptamer & Zearalenone (ZEN) & $\begin{array}{l}1-480 \mathrm{ng} / \mathrm{mL} \\
0.102 \mathrm{ng} / \mathrm{mL}\end{array}$ & ND & Beer & $\begin{array}{l}\text { Reusable by cutting and } \\
\text { polishing a tip of } \\
\text { optical fiber. }\end{array}$ & [80] \\
\hline & Optical fiber & Anti-IgG antibody & IgG & $\begin{array}{c}1 \mathrm{fg} / \mathrm{mL} \text { to } \\
100 \mathrm{fg} / \mathrm{mL}, 7 \mathrm{aM}\end{array}$ & $25-30 \mathrm{~min}$ & ND & $\begin{array}{l}\text { Use of silver enhancer: } \\
\text { amplifying the LSPR signal } \\
\text { by catalytic reduction of } \\
\text { silver around AuNPs. } \\
\text { Use of U-bent optical fiber. }\end{array}$ & [90] \\
\hline
\end{tabular}


Table 1. Cont.

\begin{tabular}{|c|c|c|c|c|c|c|c|c|}
\hline Classification & Substrate & Receptor & Analyte & Linear Range, LOD & Assay Time & $\begin{array}{l}\text { Real } \\
\text { Sample }\end{array}$ & Features & Reference \\
\hline & Optical fiber & IgG antibody & Staphylococcus aureus & $3.1 \mathrm{CFU} / \mathrm{mL}$ & ND & ND & $\begin{array}{l}\text { Use of the tapered } \\
\text { singlemode-no } \\
\text { core-singlemode fiber } \\
\text { coupler structure. }\end{array}$ & [78] \\
\hline & $\begin{array}{l}\mathrm{MoS}_{2} / \text { AuNPs- } \\
\text { coated } \\
\text { optical fiber }\end{array}$ & Aptamer & Shigella sonnei & $\begin{array}{c}1-1 \times 10^{9} \\
1.56 \mathrm{CFU} / \mathrm{mL}\end{array}$ & $5 \mathrm{~min}$ & ND & $\begin{array}{l}\text { Use of single mode } \\
\text { fiber-multi-core } \\
\text { fiber structure. }\end{array}$ & [91] \\
\hline & $\begin{array}{l}\text { AuPd alloy-coated } \\
\text { plastic optical fiber }\end{array}$ & Anti-cortisol & Cortisol & $1 \mathrm{pg} / \mathrm{mL}$ & ND & ND & Use of plastic optical fiber. & [92] \\
\hline & $\begin{array}{l}\text { Au film-coated } \\
\text { optical fiber }\end{array}$ & $\begin{array}{c}\text { Aptamer, } \\
\text { HER2 antibody }\end{array}$ & $\begin{array}{l}\text { Breast cancer } \\
\text { HER2 protein }\end{array}$ & 9.3 ng/mL (77.4 pM) & $10 \mathrm{~min}$ & ND & $\begin{array}{l}\text { HER2 biomarker detection } \\
\text { using sandwich assay with } \\
\text { anti-HER2 ssDNA aptamer } \\
\text { and HER2 antibody. }\end{array}$ & [93] \\
\hline & $\begin{array}{l}\mathrm{ZnO} / \text { AuNP-coated } \\
\text { optical fiber }\end{array}$ & Ascorbate oxidase & Ascorbic acid & $\begin{array}{c}1 \mu \mathrm{M} \text { to } 200 \mu \mathrm{M}, \\
12.56 \mu \mathrm{M}\end{array}$ & ND & ND & $\begin{array}{l}\text { Use of tapered optical fiber } \\
\text { structure immobilized with } \\
\text { ZnO-AuNPs. }\end{array}$ & [81] \\
\hline & $\begin{array}{l}\text { AuNP-modified the } \\
\text { bare core }\end{array}$ & Probe DNA & $\mathrm{Hg}^{2+}$ & $1-50 \mathrm{nM}, 0.7 \mathrm{nM}$ & ND & Pond water & $\begin{array}{l}\text { Functionalization of } \\
\text { DNA-attached Au NP } \\
\text { monolayer on optical fibers, } \\
\text { resulting in an increase in } \\
\text { the refractive index at the } \\
\text { nanometer length region } \\
\text { and near field coupling } \\
\text { enhancement produced by } \\
\text { close proximity to } \\
\text { another-attached Au NPs } \\
\text { via DNA-DNA } \\
\text { hybridization } \\
\text { Use of PAH, yielding } \\
\text { enhanced sensitivity due to } \\
\text { the higher density and less } \\
\text { aggregation of Au NPs } \\
\text { Reusability by dipping } \\
\text { optical fiber into } 1 \% \text { SDS } \\
\text { solution for } 5 \text { min }\end{array}$ & [75]; Figure 4C \\
\hline
\end{tabular}

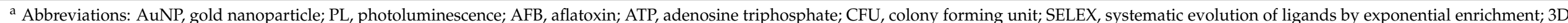

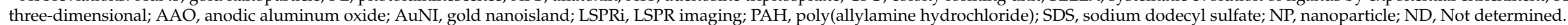


Table 2. Challenges and strategies to improve the performance of LSPR biosensors for the detection of various molecules ${ }^{\text {a }}$.

\begin{tabular}{|c|c|c|}
\hline Challenge & Performance Improvement Strategies & Reference(s) \\
\hline \multirow{9}{*}{ Sensitivity } & Conjugation of Qdots & [7] \\
\hline & NP core-satellite structure & [36] \\
\hline & Use of heteroassembled sandwich structure with multiple layers of Au NPs & [59] \\
\hline & Use of LSPR signal enhancer molecule (e.g., berberine) & [61] \\
\hline & Combining LSPR and electrochemical sensing & [67] \\
\hline & Incorporation of enzyme reaction-assisted signal amplification & [63] \\
\hline & Construction of a 3D nanocup platform & [50] \\
\hline & Implementation of a split aptamer & [124] \\
\hline & Integration of microfluidics & {$[78,116,125]$} \\
\hline \multirow{5}{*}{ Low cost, Large scale fabrication } & Incorporation of silver enhancement using catalytic reduction of silver around AuNPs. & [90] \\
\hline & Use of copper & {$[66]$} \\
\hline & Use of PDMS & {$[50]$} \\
\hline & Use of silicon as a substrate & {$[65]$} \\
\hline & Use of plastic optical fiber & [92] \\
\hline Quantification & Use of double calibration curve method & {$[40]$} \\
\hline \multirow{2}{*}{ Multiple detection } & Use of NPs with different sizes and shapes & [31] \\
\hline & Integration of microfluidic system containing multiple channels & [78] \\
\hline \multirow{2}{*}{ Real-time detection } & Combined system consisting of microfluidic on-chip PCR and LSPRi & [116] \\
\hline & Use of a microfluidic nanoplasmonic platform & [125] \\
\hline Reproducibility & $\begin{array}{c}\text { Fabrication of periodically ordered array using PS with different sizes via the } \\
\text { imprinting method }\end{array}$ & [50] \\
\hline Reusability & $\begin{array}{l}\text { Washing with solution such as PBS or containing SDS } \\
\text { Cutting and polishing a tip of optical fiber }\end{array}$ & {$[75,79,81]$} \\
\hline
\end{tabular}

a Abbreviations: Qdot, quantum dot; NP, nanoparticle; 3D, three-dimensional; PDMS, polydimethylsiloxane; LSPRi, LSPR imaging; PS, polystyrene.

This review discusses a diverse range of approaches that have been proposed for the development of LSPR biosensors. The future development of diverse plasmonic materials, nanostructure architectures, surface modifications, and receptors will play an increasingly critical role in the advancement of LSPR sensing technologies for biomolecule sensing in clinical and environmental settings. Additionally, the fields of nanotechnology and biotechnology will undoubtedly continue to make important breakthroughs toward the development of biosensors.

Author Contributions: Conceptualization, D.M.K. and S.M.Y.; Writing, D.M.K., J.S.P., S.-W.J., J.Y. and S.M.Y.; Supervision, S.M.Y.; Funding Acquisition, S.M.Y. All authors have read and agreed to the published version of the manuscript.

Funding: This work was supported by an NRF grant funded by the Ministry of Science and ICT (grant number NRF-2019R1A2C1088504) and the Chung-Ang University Graduate Research Scholarship Grant in 2019.

Institutional Review Board Statement: Not applicable.

Informed Consent Statement: Not applicable.

Data Availability Statement: No new data were created in this study. Data sharing is not applicable to this article.

Conflicts of Interest: The authors declare no conflict of interest.

\section{References}

1. Yoo, S.M.; Lee, S.Y. Optical biosensors for the detection of pathogenic microorganisms. Trends Biotechnol. 2016, 34, 7-25. [CrossRef] [PubMed]

2. Olaru, A.; Bala, C.; Jaffrezic-Renault, N.; Aboul-Enein, H.Y. Surface plasmon resonance (SPR) biosensors in pharmaceutical analysis. Crit. Rev. Anal. Chem. 2015, 45, 97-105. [CrossRef] [PubMed]

3. Jain, S.; Paliwal, A.; Gupta, V.; Tomar, M. Refractive index tuning of $\mathrm{SiO}_{2}$ for long range surface plasmon resonance based biosensor. Biosens. Bioelectron. 2020, 168, 112508. [CrossRef] [PubMed]

4. Zong, C.; Xu, M.; Xu, L.-J.; Wei, T.; Ma, X.; Zheng, X.-S.; Hu, R.; Ren, B. Surface-enhanced Raman spectroscopy for bioanalysis: Reliability and challenges. Chem. Rev. 2018, 118, 4946-4980. [CrossRef] [PubMed] 
5. Lenzi, E.; Jimenez de Aberasturi, D.; Liz-Marzan, L.M. Surface-enhanced Raman scattering tags for three-dimensional bioimaging and biomarker detection. ACS Sens. 2019, 4, 1126-1137. [CrossRef]

6. Qi, M.; Zhang, N.M.Y.; Li, K.; Tjin, S.C.; Wei, L. Hybrid plasmonic fiber-optic sensors. Sensors 2020, 20, 3266. [CrossRef]

7. Adegoke, O.; Park, E.Y. Bright luminescent optically engineered core/alloyed shell quantum dots: An ultrasensitive signal transducer for dengue virus RNA via localized surface plasmon resonance-induced hairpin hybridization. J. Mater. Chem. B 2017, 5, 3047-3058. [CrossRef]

8. Csáki, A.; Stranik, O.; Fritzsche, W. Localized surface plasmon resonance based biosensing. Expert Rev. Mol. Diagn. 2018, 18, 279-296. [CrossRef]

9. Zhang, Z.; Wang, H.; Chen, Z.; Wang, X.; Choo, J.; Chen, L. Plasmonic colorimetric sensors based on etching and growth of noble metal nanoparticles: Strategies and applications. Biosens. Bioelectron. 2018, 114, 52-65. [CrossRef]

10. Li, Z.; Leustean, L.; Inci, F.; Zheng, M.; Demirci, U.; Wang, S. Plasmonic-based platforms for diagnosis of infectious diseases at the point-of-care. Biotechnol. Adv. 2019, 37, 107440. [CrossRef] [PubMed]

11. Unser, S.; Bruzas, I.; He, J.; Sagle, L. Localized surface plasmon resonance biosensing: Current challenges and approaches. Sensors 2015, 15, 15684-15716. [CrossRef] [PubMed]

12. Gandhi, M.; Chu, S.; Senthilnathan, K.; Babu, P.R.; Nakkeeran, K.; Li, Q. Recent advances in plasmonic sensor-based fiber optic probes for biological applications. Appl. Sci. 2019, 9, 949. [CrossRef]

13. Mayer, K.M.; Hafner, J.H. Localized surface plasmon resonance sensors. Chem. Rev. 2011, 111, 3828-3857. [CrossRef]

14. Chen, H.; Kou, X.; Yang, Z.; Ni, W.; Wang, J. Shape-and size-dependent refractive index sensitivity of gold nanoparticles. Langmuir 2008, 24, 5233-5237. [CrossRef] [PubMed]

15. Kelly, K.L.; Coronado, E.; Zhao, L.L.; Schatz, G.C. The optical properties of metal nanoparticles: The influence of size, shape, and dielectric environment. J. Phys. Chem. B 2003, 107, 668-677. [CrossRef]

16. Miller, M.M.; Lazarides, A.A. Sensitivity of metal nanoparticle surface plasmon resonance to the dielectric environment. J. Phys. Chem. B 2005, 109, 21556-21565. [CrossRef]

17. Willets, K.A.; Van Duyne, R.P. Localized surface plasmon resonance spectroscopy and sensing. Annu. Rev. Phys. Chem. 2007, 58, 267-297. [CrossRef]

18. Camden, J.P.; Dieringer, J.A.; Wang, Y.; Masiello, D.J.; Marks, L.D.; Schatz, G.C.; Van Duyne, R.P. Probing the structure of single-molecule surface-enhanced Raman scattering hot spots. J. Am. Chem. Soc. 2008, 130, 12616-12617. [CrossRef]

19. Cottat, M.; Thioune, N.; Gabudean, A.-M.; Lidgi-Guigui, N.; Focsan, M.; Astilean, S.; de la Chapelle, M.L. Localized surface plasmon resonance (LSPR) biosensor for the protein detection. Plasmonics 2013, 8, 699-704. [CrossRef]

20. Lee, J.-H.; Kim, B.-C.; Oh, B.-K.; Choi, J.-W. Highly sensitive localized surface plasmon resonance immunosensor for label-free detection of HIV-1. Nanomedicine 2013, 9, 1018-1026. [CrossRef]

21. Haes, A.J.; Van Duyne, R.P. A unified view of propagating and localized surface plasmon resonance biosensors. Anal. Bioanal. Chem. 2004, 379, 920-930. [CrossRef] [PubMed]

22. Chen, H.; Shao, L.; Li, Q.; Wang, J. Gold nanorods and their plasmonic properties. Chem. Soc. Rev. 2013, 42, 2679-2724. [CrossRef] [PubMed]

23. Singh, A.; Pasricha, R.; Sastry, M. Ultra-low level optical detection of mercuric ions using biogenic gold nanotriangles. Analyst 2012, 137, 3083-3090. [CrossRef] [PubMed]

24. Shumaker-Parry, J.S.; Rochholz, H.; Kreiter, M. Fabrication of crescent-shaped optical antennas. Adv. Mater. 2005, 17, 2131-2134. [CrossRef]

25. Yang, H.; Owiti, E.O.; Jiang, X.; Li, S.; Liu, P.; Sun, X. Localized surface plasmon resonance dependence on misaligned truncated Ag nanoprism dimer. Nanoscale Res. Lett. 2017, 12, 1-6. [CrossRef]

26. Millstone, J.E.; Hurst, S.J.; Métraux, G.S.; Cutler, J.I.; Mirkin, C.A. Colloidal gold and silver triangular nanoprisms. Small 2009, 5, 646-664. [CrossRef]

27. Li, W.; Camargo, P.H.; Au, L.; Zhang, Q.; Rycenga, M.; Xia, Y. Etching and dimerization: A simple and versatile route to dimers of silver nanospheres with a range of sizes. Angew Chem. Int. Ed. 2010, 122, 168-172. [CrossRef]

28. Kessentini, S.; Barchiesi, D.; D'Andrea, C.; Toma, A.; Guillot, N.; Di Fabrizio, E.; Fazio, B.; Marago, O.M.; Gucciardi, P.G.; Lamy de la Chapelle, M. Gold dimer nanoantenna with slanted gap for tunable LSPR and improved SERS. J. Phys. Chem. C 2014, 118, 3209-3219. [CrossRef]

29. Ci, X.; Wu, B.; Song, M.; Liu, Y.; Chen, G.; Wu, E.; Zeng, H. Tunable Fano resonances in heterogenous Al-Ag nanorod dimers. Appl. Phys. A 2014, 117, 955-960. [CrossRef]

30. Zhang, C.; Zhu, J.; Li, J.; Zhao, J. Misalign-dependent double plasmon modes "switch" of gold triangular nanoplate dimers. J. Appl. Phys. 2015, 117, 063102. [CrossRef]

31. Kim, H.; Lee, J.U.; Song, S.; Kim, S.; Sim, S.J. A shape-code nanoplasmonic biosensor for multiplex detection of Alzheimer's disease biomarkers. Biosens. Bioelectron. 2018, 101, 96-102. [CrossRef] [PubMed]

32. Li, S.; Xu, L.; Ma, W.; Kuang, H.; Wang, L.; Xu, C. Triple Raman label-encoded gold nanoparticle trimers for simultaneous heavy metal ion detection. Small 2015, 11, 3435-3439. [CrossRef] [PubMed]

33. Wang, F.; Liu, S.; Lin, M.; Chen, X.; Lin, S.; Du, X.; Li, H.; Ye, H.; Qiu, B.; Lin, Z. Colorimetric detection of microcystin-LR based on disassembly of orient-aggregated gold nanoparticle dimers. Biosens. Bioelectron. 2015, 68, 475-480. [CrossRef] 
34. Yamazoe, S.; Takano, S.; Kurashige, W.; Yokoyama, T.; Nitta, K.; Negishi, Y.; Tsukuda, T. Hierarchy of bond stiffnesses within icosahedral-based gold clusters protected by thiolates. Nat. Commun. 2016, 7, 10414. [CrossRef] [PubMed]

35. Wagener, P.; Jakobi, J.; Rehbock, C.; Chakravadhanula, V.S.K.; Thede, C.; Wiedwald, U.; Bartsch, M.; Kienle, L.; Barcikowski, S. Solvent-surface interactions control the phase structure in laser-generated iron-gold core-shell nanoparticles. Sci. Rep. 2016, 6, 23352. [CrossRef]

36. Liu, Y.-B.; Zhai, T.-T.; Liang, Y.-Y.; Wang, Y.-B.; Xia, X.-H. Gold core-satellite nanostructure linked by oligonucleotides for detection of glutathione with LSPR scattering spectrum. Talanta 2019, 193, 123-127. [CrossRef]

37. Fang, Y.; Chang, W.-S.; Willingham, B.; Swanglap, P.; Dominguez-Medina, S.; Link, S. Plasmon emission quantum yield of single gold nanorods as a function of aspect ratio. ACS Nano 2012, 6, 7177-7184. [CrossRef]

38. Lu, G.; Zhang, T.; Li, W.; Hou, L.; Liu, J.; Gong, Q. Single-molecule spontaneous emission in the vicinity of an individual gold nanorod. J. Phys. Chem. C 2011, 115, 15822-15828. [CrossRef]

39. Zhang, T.; Lu, G.; Li, W.; Liu, J.; Hou, L.; Perriat, P.; Martini, M.; Tillement, O.; Gong, Q. Optimally designed nanoshell and matryoshka-nanoshell as a plasmonic-enhanced fluorescence probe. J. Phys. Chem. C 2012, 116, 8804-8812. [CrossRef]

40. Liu, B.; Huang, R.; Yu, Y.; Su, R.; Qi, W.; He, Z. Gold nanoparticle-aptamer-based LSPR sensing of ochratoxin A at a widened detection range by double calibration curve method. Front. Chem. 2018, 6, 94. [CrossRef]

41. Jeon, H.C.; Heo, C.J.; Lee, S.Y.; Yang, S.M. Hierarchically ordered arrays of noncircular silicon nanowires featured by holographic lithography toward a high-fidelity sensing platform. Adv. Funct. Mater. 2012, 22, 4268-4274. [CrossRef]

42. Li, W.; Xue, J.; Jiang, X.; Zhou, Z.; Ren, K.; Zhou, J. Low-cost replication of plasmonic gold nanomushroom arrays for transmissionmode and multichannel biosensing. RSC Adv. 2015, 5, 61270-61276. [CrossRef]

43. Im, H.; Lee, S.H.; Wittenberg, N.J.; Johnson, T.W.; Lindquist, N.C.; Nagpal, P.; Norris, D.J.; Oh, S.-H. Template-stripped smooth Ag nanohole arrays with silica shells for surface plasmon resonance biosensing. ACS Nano 2011, 5, 6244-6253. [CrossRef] [PubMed]

44. Alonso-González, P.; Albella, P.; Golmar, F.; Arzubiaga, L.; Casanova, F.; Hueso, L.E.; Aizpurua, J.; Hillenbrand, R. Visualizing the near-field coupling and interference of bonding and anti-bonding modes in infrared dimer nanoantennas. Opt. Express 2013, 21, 1270-1280. [CrossRef] [PubMed]

45. Muskens, O.L.; Giannini, V.; Sánchez-Gil, J.; Rivas, J.G. Optical scattering resonances of single and coupled dimer plasmonic nanoantennas. Opt. Express 2007, 15, 17736-17746. [CrossRef]

46. Hao, F.; Nehl, C.L.; Hafner, J.H.; Nordlander, P. Plasmon resonances of a gold nanostar. Nano Lett. 2007, 7, 729-732. [CrossRef]

47. Fischer, J.; Vogel, N.; Mohammadi, R.; Butt, H.-J.; Landfester, K.; Weiss, C.K.; Kreiter, M. Plasmon hybridization and strong near-field enhancements in opposing nanocrescent dimers with tunable resonances. Nanoscale 2011, 3, 4788-4797. [CrossRef]

48. Shi, W.; Sahoo, Y.; Swihart, M.T.; Prasad, P. Gold nanoshells on polystyrene cores for control of surface plasmon resonance. Langmuir 2005, 21, 1610-1617. [CrossRef]

49. Zhang, L.; Li, X.; Wang, Y.; Sun, K.; Chen, X.; Chen, H.; Zhou, J. Reproducible plasmonic nanopyramid array of various metals for highly sensitive refractometric and surface-enhanced Raman biosensing. ACS Omega 2018, 3, 14181-14187. [CrossRef]

50. Focsan, M.; Craciun, A.; Potara, M.; Leordean, C.; Vulpoi, A.; Maniu, D.; Astilean, S. Flexible and tunable 3D gold nanocups platform as plasmonic biosensor for specific dual LSPR-SERS immuno-detection. Sci. Rep. 2017, 7, 14240. [CrossRef]

51. Chang, C.-Y.; Lin, H.-T.; Lai, M.-S.; Shieh, T.-Y.; Peng, C.-C.; Shih, M.-H.; Tung, Y.-C. Flexible localized surface plasmon resonance sensor with metal-insulator-metal nanodisks on PDMS substrate. Sci. Rep. 2018, 8, 11812. [CrossRef]

52. Raghu, D.; Christodoulides, J.A.; Christophersen, M.; Liu, J.L.; Anderson, G.P.; Robitaille, M.; Byers, J.M.; Raphael, M.P. Nanoplasmonic pillars engineered for single exosome detection. PLoS ONE 2018, 13, e0202773. [CrossRef]

53. Rippa, M.; Castagna, R.; Tkachenko, V.; Zhou, J.; Petti, L. Engineered nanopatterned substrates for high-sensitive localized surface plasmon resonance: An assay on biomacromolecules. J. Mater. Chem. B 2017, 5, 5473-5478. [CrossRef]

54. Na, H.-K.; Wi, J.-S.; Son, H.Y.; Ok, J.G.; Huh, Y.-M.; Lee, T.G. Discrimination of single nucleotide mismatches using a scalable, flexible, and transparent three-dimensional nanostructure-based plasmonic miRNA sensor with high sensitivity. Biosens. Bioelectron. 2018, 113, 39-45. [CrossRef]

55. Acimovic, S.S.; Ortega, M.A.; Sanz, V.; Berthelot, J.; Garcia-Cordero, J.L.; Renger, J.; Maerkl, S.J.; Kreuzer, M.P.; Quidant, R. LSPR chip for parallel, rapid, and sensitive detection of cancer markers in serum. Nano Lett. 2014, 14, 2636-2641. [CrossRef] [PubMed]

56. Lopez, G.A.; Estevez, M.-C.; Soler, M.; Lechuga, L.M. Recent advances in nanoplasmonic biosensors: Applications and lab-on-achip integration. Nanophotonics 2017, 6, 123-136. [CrossRef]

57. Oh, S.Y.; Heo, N.S.; Shukla, S.; Cho, H.-J.; Vilian, A.E.; Kim, J.; Lee, S.Y.; Han, Y.-K.; Yoo, S.M.; Huh, Y.S. Development of gold nanoparticle-aptamer-based LSPR sensing chips for the rapid detection of Salmonella typhimurium in pork meat. Sci. Rep. 2017, 7, 10130. [CrossRef] [PubMed]

58. Shen, Q.; Li, W.; Tang, S.; Hu, Y.; Nie, Z.; Huang, Y.; Yao, S. A simple “clickable" biosensor for colorimetric detection of copper (II) ions based on unmodified gold nanoparticles. Biosens. Bioelectron. 2013, 41, 663-668. [CrossRef] [PubMed]

59. Kim, J.; Oh, S.Y.; Shukla, S.; Hong, S.B.; Heo, N.S.; Bajpai, V.K.; Chun, H.S.; Jo, C.-H.; Choi, B.G.; Huh, Y.S. Heteroassembled gold nanoparticles with sandwich-immunoassay LSPR chip format for rapid and sensitive detection of hepatitis B virus surface antigen (HBsAg). Biosens. Bioelectron. 2018, 107, 118-122. [CrossRef] [PubMed]

60. Oh, S.Y.; Heo, N.S.; Bajpai, V.K.; Jang, S.-C.; Ok, G.; Cho, Y.; Huh, Y.S. Development of a cuvette-based LSPR sensor chip using a plasmonically active transparent strip. Front. Bioeng. Biotechnol. 2019, 7, 299. [CrossRef] [PubMed] 
61. Park, J.-H.; Byun, J.-Y.; Jang, H.; Hong, D.; Kim, M.-G. A highly sensitive and widely adaptable plasmonic aptasensor using berberine for small-molecule detection. Biosens. Bioelectron. 2017, 97, 292-298. [CrossRef] [PubMed]

62. Jo, S.; Lee, W.; Park, J.; Park, H.; Kim, M.; Kim, W.; Hong, J.; Park, J. Wide-range direct detection of 25-hydroxyvitamin $\mathrm{D}_{3}$ using polyethylene-glycol-free gold nanorod based on LSPR aptasensor. Biosens. Bioelectron. 2021, 181, 113118. [CrossRef] [PubMed]

63. Ki, J.; Lee, H.Y.; Son, H.Y.; Huh, Y.-M.; Haam, S. Sensitive plasmonic detection of miR-10b in biological samples using enzymeassisted target recycling and developed LSPR probe. ACS Appl. Mater. Interfaces 2019, 11, 18923-18929. [CrossRef] [PubMed]

64. Kim, D.M.; Yoo, S.M. DNA-modifying enzyme reaction-based biosensors for disease diagnostics: Recent biotechnological advances and future perspectives. Crit. Rev. Biotechnol. 2020, 40, 787-803. [CrossRef] [PubMed]

65. Austin Suthanthiraraj, P.P.A.; Sen, A.K. Localized surface plasmon resonance (LSPR) biosensor based on thermally annealed silver nanostructures with on-chip blood-plasma separation for the detection of dengue non-structural protein NS1 antigen. Biosens. Bioelectron. 2019, 132, 38-46. [CrossRef]

66. Kim, D.-K.; Yoo, S.M.; Park, T.J.; Yoshikawa, H.; Tamiya, E.; Park, J.Y.; Lee, S.Y. Plasmonic properties of the multispot coppercapped nanoparticle array chip and its application to optical biosensors for pathogen detection of multiplex DNAs. Anal. Chem. 2011, 83, 6215-6222. [CrossRef]

67. Li, S.; Liu, J.; Lu, Y.; Zhu, L.; Li, C.; Hu, L.; Li, J.; Jiang, J.; Low, S.; Liu, Q. Mutual promotion of electrochemical-localized surface plasmon resonance on nanochip for sensitive sialic acid detection. Biosens. Bioelectron. 2018, 117, 32-39. [CrossRef]

68. Valsecchi, C.; Jones, T.; Wang, C.; Lochbihler, H.; Menezes, J.W.; Brolo, A.G. Low-cost leukemic serum marker screening using large area nanohole arrays on plastic substrates. ACS Sens. 2016, 1, 1103-1109. [CrossRef]

69. Kahraman, M.; Daggumati, P.; Kurtulus, O.; Seker, E.; Wachsmann-Hogiu, S. Fabrication and characterization of flexible and tunable plasmonic nanostructures. Sci. Rep. 2013, 3, 3396. [CrossRef]

70. Kahraman, M.; Wachsmann-Hogiu, S. Label-free and direct protein detection on 3D plasmonic nanovoid structures using surface-enhanced Raman scattering. Anal. Chim. Acta. 2015, 856, 74-81. [CrossRef]

71. Lee, C.; Carney, R.P.; Hazari, S.; Smith, Z.J.; Knudson, A.; Robertson, C.S.; Lam, K.S.; Wachsmann-Hogiu, S. 3D plasmonic nanobowl platform for the study of exosomes in solution. Nanoscale 2015, 7, 9290-9297. [CrossRef] [PubMed]

72. Khateb, H.; Klös, G.; Meyer, R.L.; Sutherland, D.S. Development of a label-free LSPR-apta sensor for Staphylococcus aureus detection. ACS Appl. Biol. Mater. 2020, 3, 3066-3077. [CrossRef]

73. Kaye, S.; Zeng, Z.; Sanders, M.; Chittur, K.; Koelle, P.M.; Lindquist, R.; Manne, U.; Lin, Y.; Wei, J. Label-free detection of DNA hybridization with a compact LSPR-based fiber-optic sensor. Analyst 2017, 142, 1974-1981. [CrossRef]

74. Lee, B.; Park, J.-H.; Byun, J.-Y.; Kim, J.H.; Kim, M.-G. An optical fiber-based LSPR aptasensor for simple and rapid in-situ detection of ochratoxin A. Biosens. Bioelectron. 2018, 102, 504-509. [CrossRef] [PubMed]

75. Jia, S.; Bian, C.; Sun, J.; Tong, J.; Xia, S. A wavelength-modulated localized surface plasmon resonance (LSPR) optical fiber sensor for sensitive detection of mercury (II) ion by gold nanoparticles-DNA conjugates. Biosens. Bioelectron. 2018, 114, 15-21. [CrossRef]

76. Li, C.; Li, Z.; Li, S.; Zhang, Y.; Sun, B.; Yu, Y.; Ren, H.; Jiang, S.; Yue, W. LSPR optical fiber biosensor based on a 3D composite structure of gold nanoparticles and multilayer graphene films. Opt. Express 2020, 28, 6071-6083. [CrossRef]

77. Caucheteur, C.; Guo, T.; Albert, J. Review of plasmonic fiber optic biochemical sensors: Improving the limit of detection. Anal. Bioanal. Chem. 2015, 407, 3883-3897. [CrossRef]

78. Chen, L.; Leng, Y.-K.; Liu, B.; Liu, J.; Wan, S.-P.; Wu, T.; Yuan, J.; Shao, L.; Gu, G.; Fu, Y.Q.; et al. Ultrahigh-sensitivity label-free optical fiber biosensor based on a tapered singlemode- no core-singlemode coupler for Staphylococcus aureus detection. Sens. Actuators B Chem. 2020, 320, 128283.

79. Singh, R.; Kumar, S.; Liu, F.Z.; Shuang, C.; Zhang, B.; Jha, R.; Kaushik, B.K. Etched multicore fiber sensor using copper oxide and gold nanoparticles decorated graphene oxide structure for cancer cells detection. Biosens. Bioelectron. 2020, $168,112557$. [CrossRef] [PubMed]

80. Xu, Y.; Xiong, M.; Yan, H. A portable optical fiber biosensor for the detection of zearalenone based on the localized surface plasmon resonance. Sens. Actuators B Chem. 2021, 336, 129752. [CrossRef]

81. Zhu, G.; Singh, L.; Wang, Y.; Singh, R.; Zhang, B.; Liu, F.; Kaushik, B.K.; Kumar, S. Tapered optical fiber-based LSPR biosensor for ascorbic acid detection. Photonic Sens. 2020. [CrossRef]

82. Gao, S.; Qiu, H.; Zhang, C.; Jiang, S.; Li, Z.; Liu, X.; Yue, W.; Yang, C.; Huo, Y.; Feng, D. Absorbance response of a graphene oxide coated U-bent optical fiber sensor for aqueous ethanol detection. RSC Adv. 2016, 6, 15808-15815. [CrossRef]

83. Zakaria, R.; Kam, W.; Ong, Y.; Yusoff, S.; Ahmad, H.; Mohammed, W.S. Fabrication and simulation studies on D-shaped optical fiber sensor via surface plasmon resonance. J. Mod. Opt. 2017, 64, 1443-1449. [CrossRef]

84. Al-Qazwini, Y.; Noor, A.; Yaacob, M.H.; Harun, S.W.; Mahdi, M. Experimental realization and performance evaluation of refractive index SPR sensor based on unmasked short tapered multimode-fiber operating in aqueous environments. Sens. Actuators A Phys. 2015, 236, 38-43. [CrossRef]

85. Kumar, S.; Kaushik, B.K.; Singh, R.; Chen, N.-K.; Yang, Q.S.; Zhang, X.; Wang, W.; Zhang, B. LSPR-based cholesterol biosensor using a tapered optical fiber structure. Biomed. Opt. Express 2019, 10, 2150-2160. [CrossRef] [PubMed]

86. Bharadwaj, R.; Mukherji, S.; Mukherji, S. Probing the localized surface plasmon field of a gold nanoparticle-based fibre optic biosensor. Plasmonics 2016, 11, 753-761. [CrossRef]

87. Shao, Y.; Xu, S.; Zheng, X.; Wang, Y.; Xu, W. Optical fiber LSPR biosensor prepared by gold nanoparticle assembly on polyelectrolyte multilayer. Sensors 2010, 10, 3585-3596. [CrossRef] 
88. Hall, W.P.; Modica, J.; Anker, J.; Lin, Y.; Mrksich, M.; Van Duyne, R.P. A conformation-and ion-sensitive plasmonic biosensor. Nano Lett. 2011, 11, 1098-1105. [CrossRef]

89. Zhao, J.; Das, A.; Zhang, X.; Schatz, G.C.; Sligar, S.G.; Van Duyne, R.P. Resonance surface plasmon spectroscopy: Low molecular weight substrate binding to cytochrome P450. J. Am. Chem. Soc. 2006, 128, 11004-11005. [CrossRef]

90. Bandaru, R.; Divagar, M.; Khanna, S.; Danny, C.G.; Gupta, S.; Janakiraman, V.; Sai, V.V.R. U-bent fiber optic plasmonic biosensor platform for ultrasensitive analyte detection. Sens. Actuators B Chem. 2020, 321, 128463. [CrossRef]

91. Kumar, S.; Guo, Z.; Singh, R.; Wang, Q. $\mathrm{MoS}_{2}$ functionalized multicore fiber probes for selective detection of shigella bacteria based on localized plasmon. J. Lightw. Technol. 2020. [CrossRef]

92. Leitão, C.; Leal-Junior, A.; Almeida, A.R.; Pereira, S.O.; Costa, F.M.; Pinto, J.L.; Marques, C. Cortisol AuPd plasmonic unclad POF biosensor. Biotechnol. Rep. 2021, 29, e00587. [CrossRef] [PubMed]

93. Loyez, M.; Lobry, M.; Hassan, E.M.; De Rosa, M.C.; Caucheteur, C.; Wattiez, R. HER2 breast cancer biomarker detection using a sandwich optical fiber assay. Talanta 2021, 221, 121452. [CrossRef] [PubMed]

94. Aćimović, S.S.; Šípová, H.; Emilsson, G.; Dahlin, A.B.; Antosiewicz, T.J.; Käll, M. Superior LSPR substrates based on electromagnetic decoupling for on-a-chip high-throughput label-free biosensing. Light Sci. Appl. 2017, 6, e17042. [CrossRef] [PubMed]

95. Augel, L.; Berkmann, F.; Latta, D.; Fischer, I.A.; Bechler, S.; Elogail, Y.; Kostecki, K.; Potje-Kamloth, K.; Schulze, J. Optofluidic sensor system with Ge PIN photodetector for CMOS-compatible sensing. Microfluid. Nanofluid. 2017, 21, 1-5. [CrossRef]

96. Liu, Y.; Zhang, N.; Li, P.; Yu, L.; Chen, S.; Zhang, Y.; Jing, Z.; Peng, W. Low-cost localized surface plasmon resonance biosensing platform with a response enhancement for protein detection. Nanomaterials 2019, 9, 1019. [CrossRef] [PubMed]

97. Shakoor, A.; Cheah, B.C.; Hao, D.; Al-Rawhani, M.; Nagy, B.; Grant, J.; Dale, C.; Keegan, N.; McNeil, C.; Cumming, D.R. Plasmonic sensor monolithically integrated with a CMOS photodiode. ACS Photonics 2016, 3, 1926-1933. [CrossRef]

98. Nguyen, V.-T.; Kwon, Y.S.; Kim, J.H.; Gu, M.B. Multiple GO-SELEX for efficient screening of flexible aptamers. Chem. Commun. 2014, 50, 10513-10516. [CrossRef] [PubMed]

99. Dwivedi, H.P.; Smiley, R.D.; Jaykus, L.-A. Selection of DNA aptamers for capture and detection of Salmonella typhimurium using a whole-cell SELEX approach in conjunction with cell sorting. Appl. Microbiol. Biotechnol. 2013, 97, 3677-3686. [CrossRef]

100. Kwon, Y.S.; Raston, N.H.A.; Gu, M.B. An ultra-sensitive colorimetric detection of tetracyclines using the shortest aptamer with highly enhanced affinity. Chem. Commun. 2014, 50, 40-42. [CrossRef]

101. Chen, Y.; Xianyu, Y.; Wu, J.; Yin, B.; Jiang, X. Click chemistry-mediated nanosensors for biochemical assays. Theranostics 2016, 6, 969. [CrossRef]

102. Zhou, Q.-Y.; Yuan, F.; Zhang, X.-H.; Zhou, Y.-L.; Zhang, X.-X. Simultaneous multiple single nucleotide polymorphism detection based on click chemistry combined with DNA-encoded probes. Chem. Sci. 2018, 9, 3335-3340. [CrossRef]

103. Ma, K.; Zhou, N.; Yuan, M.; Li, D.; Yang, D. Tunable surface plasmon resonance frequencies of monodisperse indium tin oxide nanoparticles by controlling composition, size, and morphology. Nanoscale Res. Lett. 2014, 9, 1-7. [CrossRef]

104. Manthiram, K.; Alivisatos, A.P. Tunable localized surface plasmon resonances in tungsten oxide nanocrystals. J. Am. Chem. Soc. 2012, 134, 3995-3998. [CrossRef]

105. Wieneke, R.; Raulf, A.; Kollmannsperger, A.; Heilemann, M.; Tampé, R. SLAP: Small labeling pair for single-molecule superresolution imaging. Angew Chem. Int. Ed. 2015, 54, 10216-10219. [CrossRef]

106. Hoffmann, J.E.; Plass, T.; Nikić, I.; Aramburu, I.V.; Koehler, C.; Gillandt, H.; Lemke, E.A.; Schultz, C. Highly stable transcyclooctene amino Acids for live-cell labeling. Chem. Eur. J. 2015, 21, 12266-12270. [CrossRef]

107. Zhang, P.; Liu, S.; Gao, D.; Hu, D.; Gong, P.; Sheng, Z.; Deng, J.; Ma, Y.; Cai, L. Click-functionalized compact quantum dots protected by multidentate-imidazole ligands: Conjugation-ready nanotags for living-virus labeling and imaging. J. Am. Chem. Soc. 2012, 134, 8388-8391. [CrossRef]

108. Pan, H.; Zhang, P.; Gao, D.; Zhang, Y.; Li, P.; Liu, L.; Wang, C.; Wang, H.; Ma, Y.; Cai, L. Noninvasive visualization of respiratory viral infection using bioorthogonal conjugated near-infrared-emitting quantum dots. ACS Nano 2014, 8, 5468-5477. [CrossRef]

109. Seker, U.O.S.; Demir, H.V. Material binding peptides for nanotechnology. Molecules 2011, 16, 1426-1451. [CrossRef]

110. Wright, L.B.; Palafox-Hernandez, J.P.; Rodger, P.M.; Corni, S.; Walsh, T.R. Facet selectivity in gold binding peptides: Exploiting interfacial water structure. Chem. Sci. 2015, 6, 5204-5214. [CrossRef]

111. Kodama, T.; Yoshihara, A.; Goel, I.; Sekino, M.; Kuwahata, A.; Yoshimori, A.; Murayama, Y.; Ishihara, K.; Ekdahl, K.N.; Nilsson, B. Identification of metal-binding peptides and their conjugation onto nanoparticles of superparamagnetic iron oxides and liposomes. ACS Appl. Mater. Interfaces 2020, 12, 24623-24634. [CrossRef] [PubMed]

112. Akcapinar, G.B.; Sezerman, O.U. Computational approaches for de novo design and redesign of metal-binding sites on proteins. Biosci. Rep. 2017, 37. [CrossRef] [PubMed]

113. Haberal, I.; Oğul, H. Prediction of protein metal binding sites using deep neural networks. Mol. Inform. 2019, 38 , 1800169. [CrossRef]

114. Chang, K.; Wang, S.; Zhang, H.; Guo, Q.; Hu, X.; Lin, Z.; Sun, H.; Jiang, M.; Hu, J. Colorimetric detection of melamine in milk by using gold nanoparticles-based LSPR via optical fibers. PLoS ONE 2017, 12, e0177131. [CrossRef] [PubMed]

115. Ha, S.-J.; Park, J.-H.; Lee, B.; Kim, M.-G. Label-free direct detection of saxitoxin based on a localized surface plasmon resonance aptasensor. Toxins 2019, 11, 274. [CrossRef] [PubMed] 
116. Haber, J.; Gascoyne, P.; Sokolov, K. Rapid real-time recirculating PCR using localized surface plasmon resonance (LSPR) and piezo-electric pumping. Lab. Chip. 2017, 17, 2821-2830. [CrossRef]

117. Zandieh, M.; Hosseini, S.N.; Vossoughi, M.; Khatami, M.; Abbasian, S.; Moshaii, A. Label-free and simple detection of endotoxins using a sensitive LSPR biosensor based on silver nanocolumns. Anal. Biochem. 2018, 548, 96-101. [CrossRef]

118. Taghavi, A.; Rahbarizadeh, F.; Abbasian, S.; Moshaii, A. Label-free LSPR prostate-specific antigen immune-sensor based on GLAD-fabricated silver nano-columns. Plasmonics 2019, 1-8. [CrossRef]

119. Ng, S.P.; Qiu, G.; Ding, N.; Lu, X.; Wu, C.-M.L. Label-free detection of 3-nitro-l-tyrosine with nickel-doped graphene localized surface plasmon resonance biosensor. Biosens. Bioelectron. 2017, 89, 468-476. [CrossRef]

120. Qiu, G.; Ng, S.P.; Liang, X.; Ding, N.; Chen, X.; Wu, C.-M.L. Label-free LSPR detection of trace lead (II) ions in drinking water by synthetic poly (mPD-co-ASA) nanoparticles on gold nanoislands. Anal. Chem. 2017, 89, 1985-1993. [CrossRef]

121. Thakur, A.; Qiu, G.; Siu-Pang, N.; Guan, J.; Yue, J.; Lee, Y.; Wu, C.-M.L. Direct detection of two different tumor-derived extracellular vesicles by SAM-AuNIs LSPR biosensor. Biosens. Bioelectron. 2017, 94, 400-407. [CrossRef] [PubMed]

122. Qiu, G.; Ng, S.P.; Wu, L.C.-M. Dielectric functionalization for differential phase detecting localized surface plasmon resonance biosensor. Sens. Actuators B Chem. 2016, 234, 247-254. [CrossRef]

123. Lv, X.; Geng, Z.; Su, Y.; Fan, Z.; Wang, S.; Fang, W.; Chen, H. Label-Free Exosome detection based on a low-cost plasmonic biosensor array integrated with microfluidics. Langmuir 2019, 35, 9816-9824. [CrossRef] [PubMed]

124. Chen, J.-S.; Chen, P.-P.; Lin, T.-H.; Huang, N.-T. A Localized surface plasmon resonance (LSPR) sensor integrated automated microfluidic system for multiplex inflammatory biomarker detection. Analyst 2020, 145, 7654. [CrossRef]

125. Roether, J.; Chu, K.-Y.; Willenbacher, N.; Shen, A.Q.; Bhalla, N. Real-time monitoring of DNA immobilization and detection of DNA polymerase activity by a microfluidic nanoplasmonic platform. Biosens. Bioelectron. 2019, 142, 111528. [CrossRef] [PubMed] 